STATE OF ALASKA

DEPARTMENT OF NATURAL RESOURCES

\title{
HYDROCARBON RESERVOIR AND SOURCE-ROCK CHARACTERISTICS FROM SELECTED AREAS OF SOUTHWESTERN ALASKA
}

$\mathrm{By}$

W.M. Lyle

Alaska Division of Geological and Geophysical Surveys

and

I.F. Palmer, Jr., J.G. Bolm, and T.O. Flett

U.S. Minerals Management Service

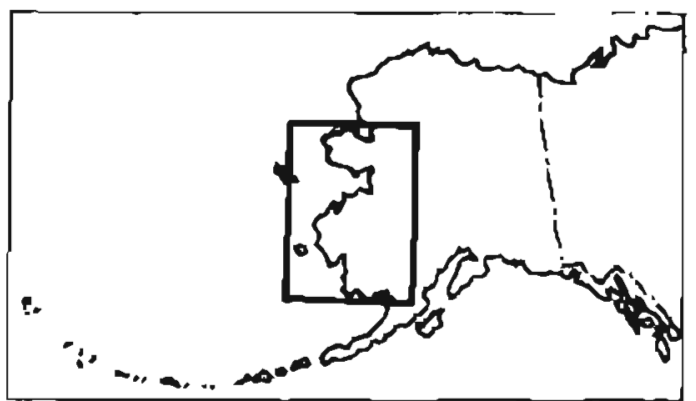

Published by

DIVISION OF GEOLOGICAL \& GEOPHYSICAL SURVEYS

ROSS G. SCHAFF

STATE GEOLOGIST

1982 


\section{HYDROCARBON RESERVOIR AND SOURCE-ROCK CHARACTERISTICS FROM SELECTED AREAS OF SOUTHWESTERN ALASKA}

By
W.M. Lyle, I.F. Palmer, Jx., J.G. Bolm, and T.O. Flett

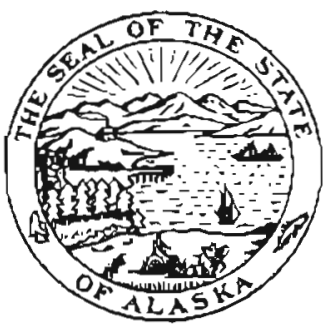




\section{STATE OF ALASKA}

Jay S. Hammond, Governor

John W. Katx, Commissioner, Depl. of Nalural Resources

Geoffrey Haynes, Depuly Commissioner

Ross G. Schaff, State Geologist

For sle by Alaske Division of Geolopical and Geophysical Surveys, P.O. Box 80007, College, 99708; 929 E. 4th, Anchorage, 99601; P.O. Box 7438, Ketchikan, 99901 : and 230 So. Franklin, Juneau, 99811 . Price: $\$ 6.60$. 


\section{CONTENTS}

Page

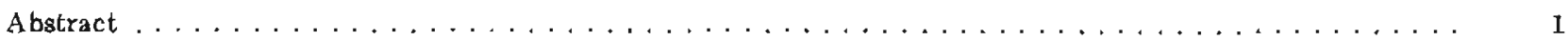

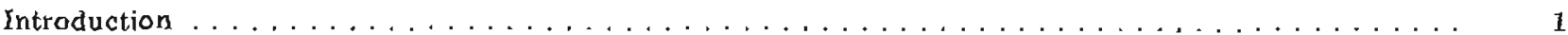

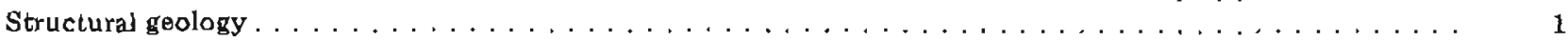

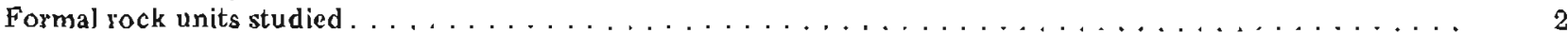

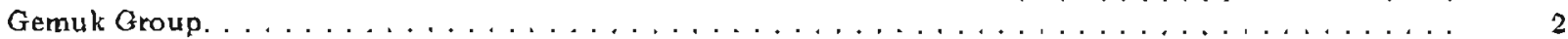

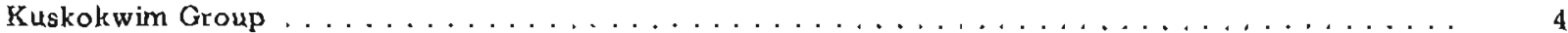

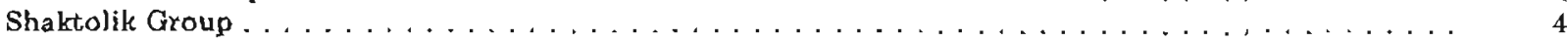

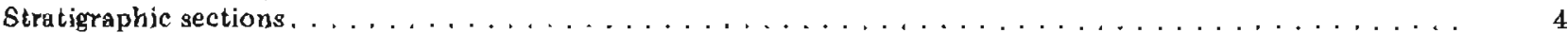

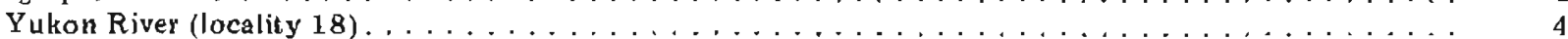

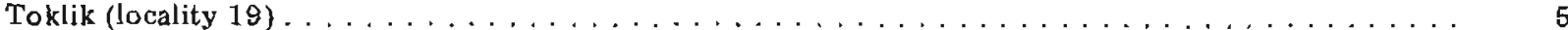

Nelson Island 1 (locality 20$) \ldots \ldots \ldots$

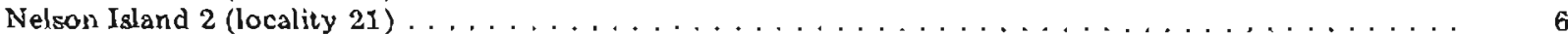

Nunivak Island (locality 22$) \ldots \ldots \ldots$

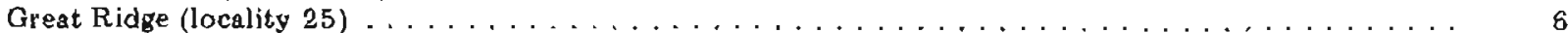

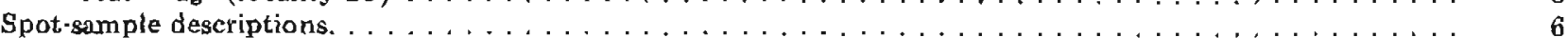

Locality $1 \ldots 6$

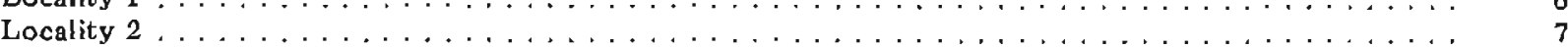

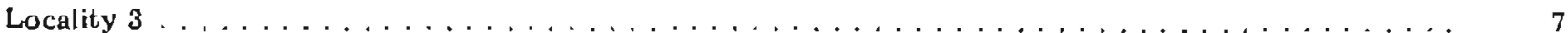

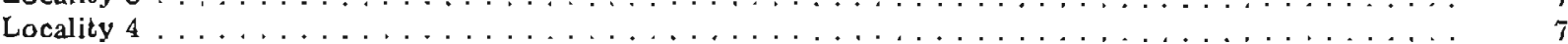

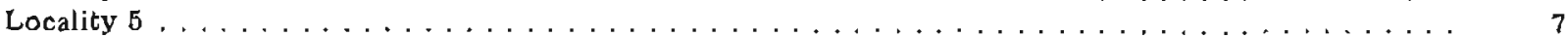

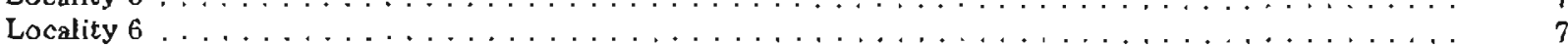

Locality $7 \ldots \ldots \ldots \ldots$

Locslity $8 \ldots \ldots \ldots \ldots$

Locality $9 \ldots \ldots \ldots \ldots \ldots$

Locality $10 \ldots \ldots \ldots$

Locality $11 \ldots \ldots \ldots \ldots \ldots$

Locality $12 \ldots \ldots \ldots \ldots \ldots$

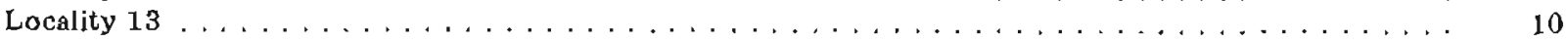

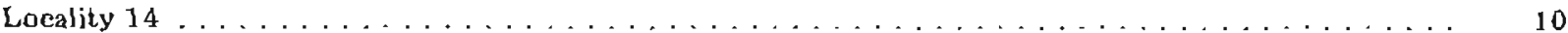

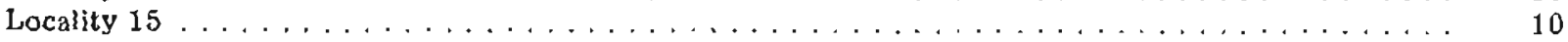

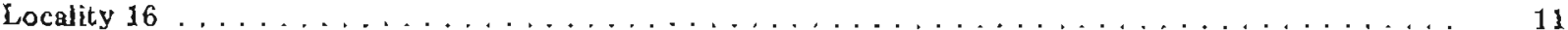

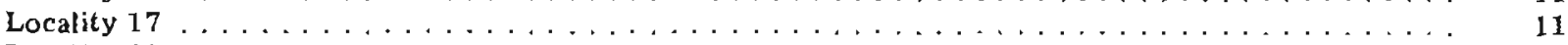

Locality $23 \ldots \ldots \ldots \ldots \ldots$

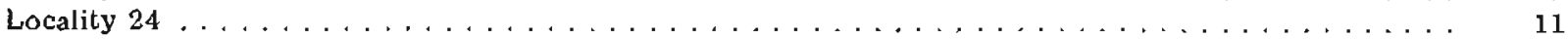

Locality $26 \ldots \ldots \ldots \ldots \ldots$

Localjty $27 \ldots \ldots \ldots \ldots \ldots \ldots$

Localjty $28 \ldots \ldots \ldots \ldots \ldots$

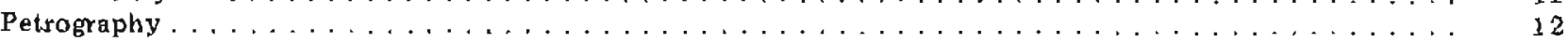

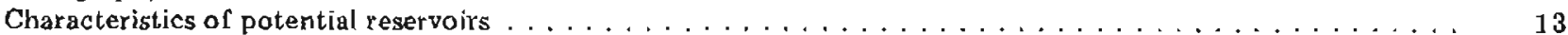

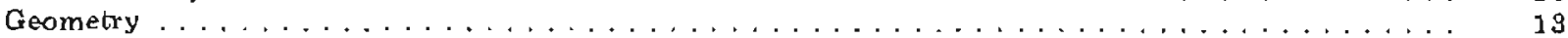

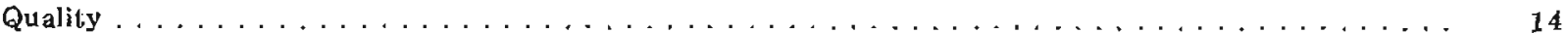

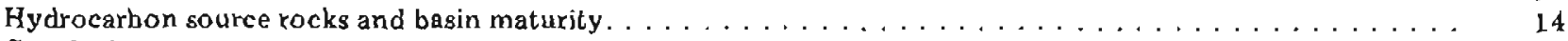

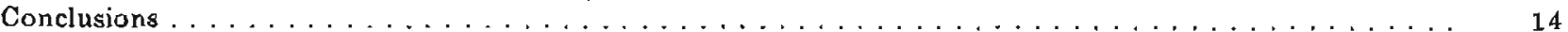

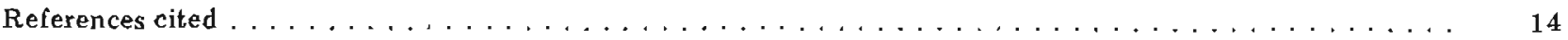

FIGURES

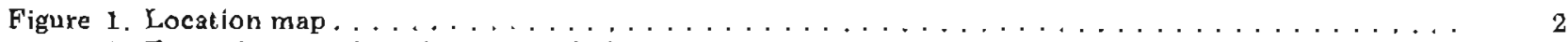

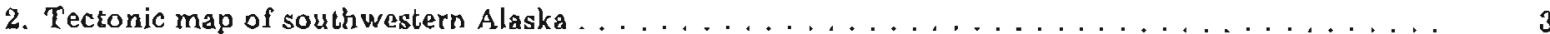

3. Soft-sediment deformation features in interbedded sandstone and siltstone of Tokjik stratigraphic section

4. Nelson Island 2 stratigraphic section. .

6. Panoramic view of Nunivak Island stratigraphic section.

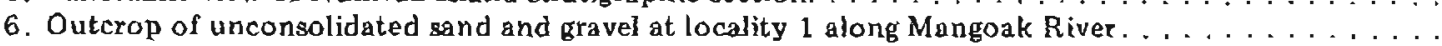

7. Coal and sandstone of Tertiary age in solifluction lobe at locality 9 on the beach south of Unalakleet. 


\section{TABLES}

Table 1. Sample numbers cross referenced to quadrangle maps, township, range, and stratigraphic unit . . . . 16

2. Summary of organic carbon content and visual kerogen data . . . . . . . . . . . . . . 17

3. Geochemical analysis of $\mathrm{C}_{15}$ extracted material in rock $\ldots \ldots \ldots \ldots$

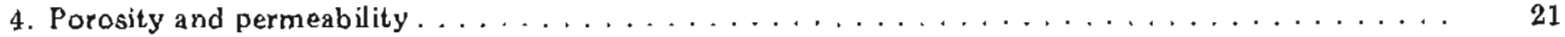

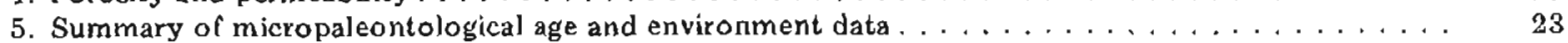

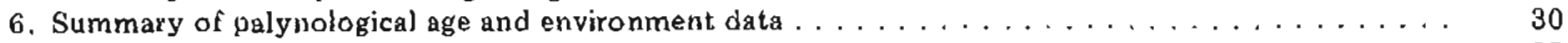

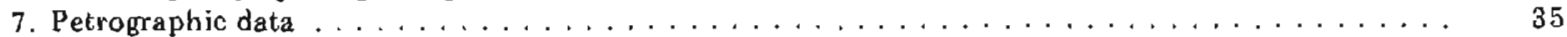

\section{PLATES}

Plate 1. Map showing sample lacalities and stratigraphic section locations, southwestern Alaska ........

2. Yukon River stratigraphic section.

3. Toklik stratigraphic section . . . .

4. Nelson Island I stratigraphic section.

5. Nelson Island 2 stratigraphic section .

6. Nunivak Island stratigraphic section

7. Great Ridge stratigraphic section

Envelope Envelope Envelope Envelope Envelope Envelope Envelope

\section{METRIC CONVERSION FACTORS}

To convert feet to meters, multiply by 0.3048 . To con. vert inches to centimeters, multiply by 2.54 . To convert miles to kilometers, multiply by 1.61 . 


\title{
HYDROCARBON RESERVOIR AND SOURCE-ROCK CHARACTERISTICS FROM SELECTED AREAS OF SOUTHWESTERN ALASKA
}

\author{
By W. M. Lyle', I.F. Palmer, Jr. ${ }^{2}$, J.G. Bolm², and T.O. Flett
}

\begin{abstract}
A joint state-federal project conducted during July 1978 in southwestern Alaska resulted in considerable new data on petroleum reservoir and source-rock potential. Six stratigraphic sections totaling 7,332 feet were measured, and 236 samples were collected from these stratigraphic seclions and various spol localities. Some potential reservoir sandstones measured at coastal exposures at Nunivak Island and Netson Island cxceed 75 feet in thickness; similar sand bodies probably exiend offshore, but their limits are unknown. Laboratory analyses of outcrop samples indicatc poor reservoir quality owing to tight packing and alteration of mineral consituents. All samples had porosities less than 10 percent, and all but (wo samples had permeabilitics less than 7 millidarcies.

On the basis of thermal-alteration indices, most samples are immature 10 mature $(2$ - to $3+)$. Mosi samples also contain dominant herbaceous and woody primary kerogen constituents. Only 13 samples have an organic carbon content greater than 0.5 percent, and exiraciable hydrocarbons averaged $48 \mathrm{ppm}$ with a range of $61099 \mathrm{ppm}$. These data show a lean hydrocarbon sourcc potential with a greater likelihood of gas than oil generation.
\end{abstract}

\section{INTRODUCTION}

Stratigraphic fietd studies were conducted in selected upland areas adjacent to Norton Sound and Kuskokwim Bay during July 1978 by the U.S. Minerals Management Service (then the Conservation division, U.S. Geological Survey) and the Alaska Division of Geological and Geophysical Surveys (fig. 1). This project was similar in scope to previous cooperative state-federal field projects completed annually since 1975 . Both agencies are charged with evaluation of petroleum potential of submerged lands under their respective jurisdictions. Because geologists from the two agencies collaborate on these projects, geological data are collected and processed uniformly, research efforts are not duplicated, and boih agencies realize significant savings. Interpretations based on dala collected are extrapolated into adjacent submerged areas and are used in evaluation programs for petroleum lease sales.

Commercial facilities at Bethel, Nome, and Unatakleet served as bases of operations. A Bell 206B Jet Ranger II helicopter was the primary means of crew Iransport in the freld, and fuel for the helicopter was cached at several remote locations by fixed-wing charler aircraft.

All stratigraphic sections but one were measured by using

Alaska Divislon of Geological and Geophysical Surveys.

${ }^{2} \mathrm{U}$.S. Minerals Managemene Servicc.
Brunion compasses and 100-foot tapes; a Jacob's slaff was used on the exccption. Samples were collected to determine porosity, permeability, age, depositional environment. hydrocarbon content, and basin maturity. Sample localities are shown on plate 1. All samples are identified with a sample number, the collector's initials, and the year (e.g.. 1-GB-78). Samples are cross-referenced 10 quadrangle map, township, range, and stratigraphic unil (table I). Results of geochemical analyses of samples appear in tables 2 and 3 , porosity and permeability data are presented in rable 4, paleontological data are presented in tables 5 and 6 , and results of petrographic studies are summarized in lable 7 . For continuity, the tables, which are lengthy, are placed at the end of the text.

\section{STRUCTURAL GEOLOGY}

The following outline of the structural geology of the investigated area is based on published work by Sainsbury and others (Seward Peninsula, 1970), Patton (YukonKoyukuk basin, 1973), and Hoare (lower KuskokwimBristol Bay region, 1961). Figure 2 shows the siructural entities mentioned in this section.

The bedrock of the Seward Peninsula consists of metamorphic rocks of Precambrian age and Paleozoic rocks that are unmetamorphosed in the west but become metamorphosed and of progressively higher grade eastward. The structure of this region is dominated by imbricate thrust sheets that are generally horizontal or gently southward-dipping in the west and become folded with a progressive increase in complexily eastward. Most folding on the Seward Peninsula is relaced to thrusting.

Two ages of thrusting are evident on the peninsula. The earlier was directed castward and was accompanied by intense folding; the later, directed northward, was not accompanied by major folding. Rocks as young as Mississippian have been cut by thrusts, and thrust sheets have been intruded by plutons of Late Cretaceous age. The absence of upper Paleozoic and lower Mesozoic rocks in the thrusc sheets precludes determination of the age of thrusting closer than post-Mississippian 10 pre-Late Cretaceous. Sainsbury and his coauthors (1970) believe it is most likely of Early Cretaceous age:

The Yukon-Xoyukuk basin is a large Cretaceous basin in which sedimentary rocks have been tightly folded and much faulted. In the western part of the basin, folds trend northsouth near the Seward Peninsula and shift to a northeasterly trend soush of that area; Patton (1973) interpreted these folds to have formed in a strong eastward compression associated with thrusting on the Seward Peninsula.

Folds trend northeastward all along the southeastern margin of the Yukon-Koyukuk basin. This is parallel to the predominant structural grain in the adjacent lower 


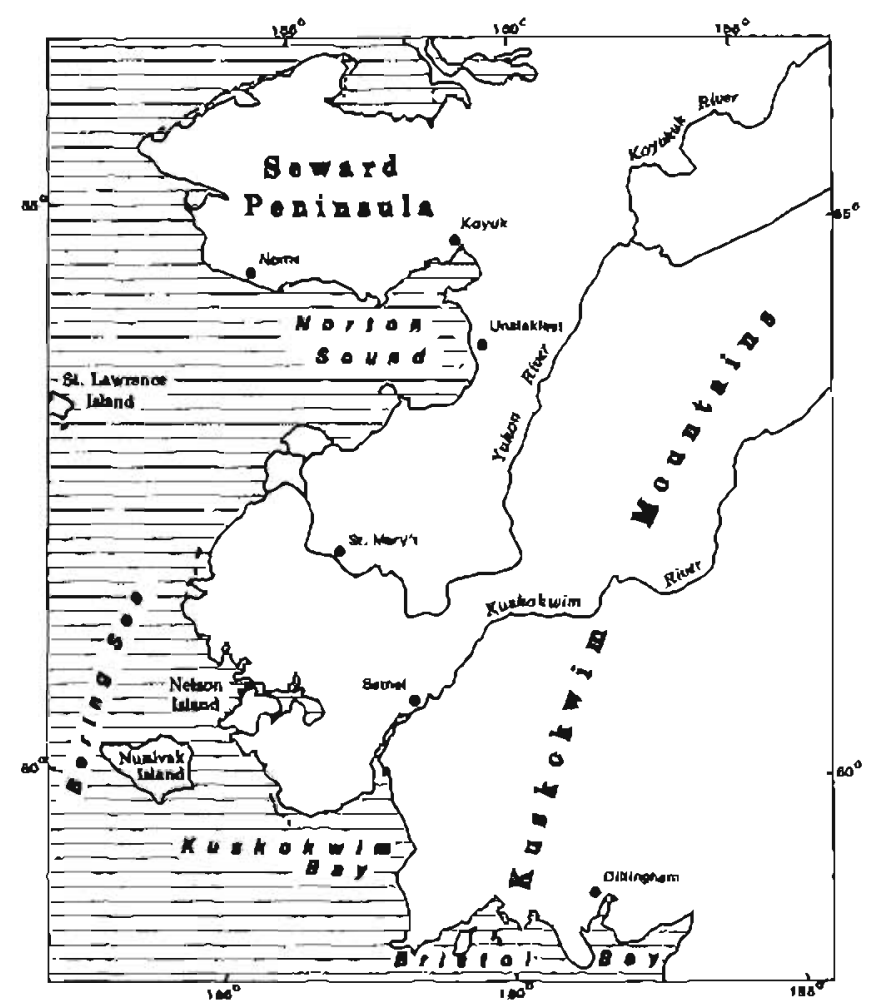

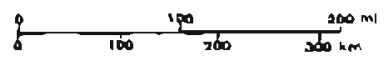

Figure 1. Location map.

Kuskokwim-Bristol Bay region.

Folds trend east-west along the northern margin of the Yukon-Koyukuk basin. The formation of this irend was associated with the rise of the ancestral Brooks Range, as was the orogenic activity that resulted in the formation of the east-west-trending Hogatza plutonic belt of Cretaceous age in the northernmost part of the study area. This belt is in an area of general uplift in which volcanic rocks of Early Cretaceous age eтоp out. These rocks separate northerly trending folded sedimentary rocks near Seward Peninsula from easterly and northeasterly treading foided sedimentary rocks along the northern and eastern margins of the basin.

The east-northeast-trending Kaltag fault cuts across the middle of the Yukon-Koyukuk basin. Right-lateral displacement across this fault has offset geologic trends in the basin by 40 to 62 miles, and recent movement along the fault is evidenced by drainage of fsets of as much as 1.5 miles.

The lower Kuskokwim-Bristol Bay regjon contains a series of northeast-trending basins and uptifs. From northwest 10 southeast these are the Ruby arch, the Kuskokwim basin, the Goodnews arch and Alaska-Yukon arch, and the Alaska Range basin.

Tectonic development began in this area in Cretaceous time with local uplift and subsidence of highly deformed, fine-grained sedimentary and volcanic rocks of Precam- brian to Early Cretaceous age. As basins formed, they were filled by sediments stripped from adjacent uplifts. Consequently, basin-fill rocks onlap limbs of arches unconformably but become more nearly conformable with underlying rocks as they approach synclinal axes. Isolated patches of Upper Cretaceous rock localed neas axes of arches indicate that onlapping Cretaceous strata once blanketed the uplifted structures. The numerous intraformational uncon* formities in the basin-fill rocks indicate that uplift and subsidence were intermiltent through middle Late Cretaceous time.

Cretaceous rocks in the basins have been intensely folded on a scale that ranges from inches to miles. Sandstones and conglomerates are generally smoothly flexed. bul folds in shales tend to be disharmonic. Fold axes trend northeasterly except in the saddle between the Goodnews arch and Alaska-Yukon arch, where folds arend northwesterly and may have formed as a result of strike-slip movement along the Farewell Gault. Hoare (1961) believes the rocks in the basins were deformed by horizontal compression, which drove more competent, uplifted structural elements logether in latest Crctaceous or earliest Tertiary time.

Major faults in the lower Kuskokwim-Bristol Bay region trend east-northeasterly. Many of these faults appear to have had Late Cretaceous or early Tertiary strike-slip movement, but more recent movemenl has been predominantly dip-slip, which indicates southeastward or northwestward compression. Offsets of alluvium across some east-northeast-trending faults in this region may be tears between areas of unequal crustal shortening.

\section{FORMAL ROCK UNITS STUDIED}

Although some stratigraphic sections were measured in and some spot samples collected from outcrops of rock that have not been assigned to any formal rock unit, most work was done in three rock units: the Gemuk, Kuskokwim, and Shakıolik Groups.

\section{GEMUK GROUP}

The Gernuk group, named by Cady and others (1955), comprises massive dark siltstone with interbedded graywacke, volcanic rocks, chert, and limestone. This group crops out extensively in and adjacent to the central and lower Kuskokwim River region. The following description is based principally on that presented in the original, defining work.

Siltstone, the principal lithology in the group, is a microbreccia of angular, equant grains of coarse silt in a matrix of finer sill and clay. This lithology grades to fine graywacke and pebble breccia.

Andesite flows and turfs are the main volcanic rock lypes in the Gemuk Group. Outcrops of flows and coarser tuffs are similar in appearance to the siltstone, and vitric tuffs are easily mistaken for chert.

Chert is present in distincl, thin beds that commonly grade into other lithologies. Sericite, chlorite, carbonate, carbon, clay minerals, and iron oxide are common inclusions in the chert, and chert beds commonly display rectilinear systems of closely spaced carbonate or silica veins. Silty chert contains probable Radiolaria and fragments of other mictofossils.

Limestone is present in scattered, lone, thin, lenticular 


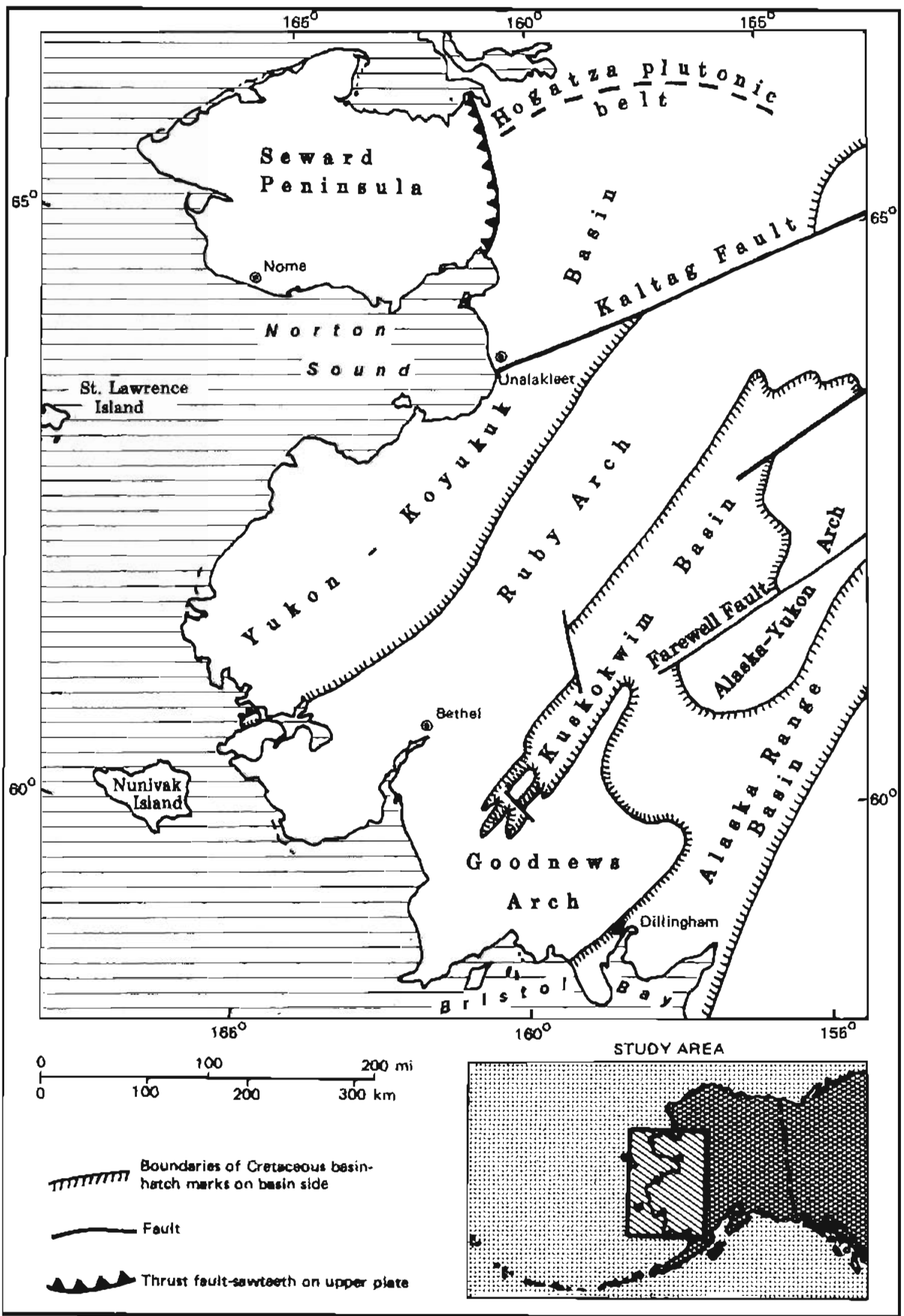

Figure 2. Tectonic map of southwestern Alaska. 
beds of fossil hash in a micritic matrix. Rectilinear systems of closely spaced carbonate veins are common in limestone beds, and insoluble residues consist mainly of quarlz and chert with lesser amounts of ferruginous material and clay.

The details of regional stratigraphy within the Gernuk Group are unknown, and the base of the group is not exposed. The thickness of exposed Gemuk Group rocks varies greatly, but the maximum exposed thickness is probably between 15,000 and 25,000 feet .

Cady and others (1955) reported Early Cretaceous and Late Triassic pelecypods from the Gernuk Group in the central Kuskokwim region and believed that unfossiliferous rocks, which seemed to be the stratigraphically lowest part of the group in that region, were probably of Permian or Carboniferous age. Hoare and Coonrad (196I) reported several collections of Possils of Permian, Triassic, and probable Carboniferous as well as Cretaceous age from the Gemuk Group in the Goodnews Quadrangle; thus, the age of the group may be taken to extend from Carboniferous to Cretaceous.

\section{KUSKOKWIM GROUP}

The Kuskokwim Group consists predominantly of interbedded sandstone and siltstone which are the principal rocks of the Kuskokwim Mountains and are widely exposed elsewhere in southwestern Alaska. The group was named by Cady and others (1955), and the following discussion is based primarily on the original, defining work.

Both sandstone and siltstone are of graywacke composition, characterized by angular grains and poor sorting. The sandstone, which is medium gray to black, consists of metamorphic rock fragments, chert, quartz, volcanic rock fragments, feldspar, sedimentary rock fragments, and mica in an abundant intergranular matrix. It is so well indurated that it fractures across grains. The composition of larger clasts varies with location relative to source terrane in the stratigraphically lower part of the group, but such correlation between clast composition and local source terrane is not evident in the upper part of the group. Larger, elongate clasts tend to be oriented parallel 10 bedding. Beds of conglomerate and breccia are present locally in the sandstone.

Siltstone is biack and compositionally similar to sandstone except that rock fragments are much less abundant because of the finer grain size. Tiny muscovite flakes in the siltstone are generally oriented parallel to bedding and produce a parting in that plane. Thin zones of well-preserved marine fossils and some minor, thin coal seams are present locally in the siltstone.

The Kuskokwim Group overlies the Gemuk Group and older rocks unconformably. Structural complexicies preclude accurate thickness determination for the Kuskok wim Group, but a thickness of 40,000 to 65,000 feet has been estimated. Massive sandstone and siltstone beds hundreds of feet thick predominate in the bottom 5,000 to 10,000 feet of the group, but in the upper part of the group, beds are seldom more than 2 feet thick.

Cady and others (1955) reported marine fossil assemblages of early and middle Late Cretaceous age from the Kuskokwim Group, and Hoare and Coonrad (1959) found fossils of Albian (late Early Cretaceous) age in the basal part of the group. Thus the Kuskokwim Group is of Albian to at least middle Late Cretaceous age.

\section{SHAKTOLIK GROUP}

The Shakıolik Group consists primarily of interbedded medium-gray to black sandstone and siltstone that crop out extensively in the area between Yukon River and Norton Sound. The group was named by Smich and Eakin (1911) for excellent exposures in cliffs along Shakcoolik River. Patton abandoned the name without suggesting any other in 1973, but we retain it for ease in referring to the appropriate rocks. The following discussion is based on work by Patlon (1973), whose description is the most comprehensive yet published.

The basal part of the Shaktolik Group comprises a thick marine turbidite sequence of interbedded volcanic graywacke and mudstone with some conglomerate near basin margins and interbedded tuff adjacent to the Hogatza plutonic belt east of Seward Peninsula. Sandstone in this part of the group consists primarily of volcanic rock fragments and plagioclase in abundant argillaceous matrix.

Alop the basal portion of the group is a sequence of shallow-marine rocks that grade into coal-bearing nonmarine rocks. In the western part of the outcrop area the shallow-marine section comprises calcareous graywacke and mudstone with abundant carbonate detritus from the Seward Peninsula and the Brooks Range. Westward, these rocks coarsen and grade into nonmarine facies that lap onto older volcanic and metamorphic terranes of Seward Peninsula and Yukon Delta. In the eastern part of the out crop area, shallow-marine sandstone and shale grade upward into nonmarine sandstone, siltstone, shale, and coal. The transition from marine to nonmarine rocks in this part of the area is locally marked by probable strandline deposits in which sorting is better and quartz and other resistant clast types are more abundant than in the group generally. The uppermost part of the Shakrolik Group is present only in the northern and northeasternmost parts of the basin and comprises quartz conglomerate.

Patton (1973) estimated a total thickness for the Shaktolik Group of more than 33,000 feet. A few isolated ammonites indicative of Albian (ate Early Cretaceous) age have been recovered from the basal (turbidite) part of the group, and some Cenomanian (early Late Cretaceous) fossils are known from the shallow-marine part of the group. Plant fossils of probable Cretaceous age have been collected from the quartz conglomerate that makes up the uppermost part of the group. Palton and Miller (1968) reported a potassium-argon radiometric age of $83.4 \pm 2.2$ m.y. from biotite from an ash-fall tuff interbedded with that conglomerate. Evidently the Shaktolik Group ranges in age from late Early Cretaceous to Late Cretacrous.

\section{STRATIGRAPHIC SECTIONS}

\section{YUKON RIVER (LOCALITY 18)}

This stratigraphic section ( $\mathrm{gl} .2$ ) is located in sec. $11, T$. 18 N., R. 69 W., where interbedded siltstone, mudstone, and minor sandstone, which were mapped as Gemuk Group by Hoare and Coonrad (1959b), crop out in the right bank of Yukon River.

Of six samples submitted for micropaleontological analysis, five were barren. The sixth contained a few Radiolaria, which suggests depostion in a marine environ- 


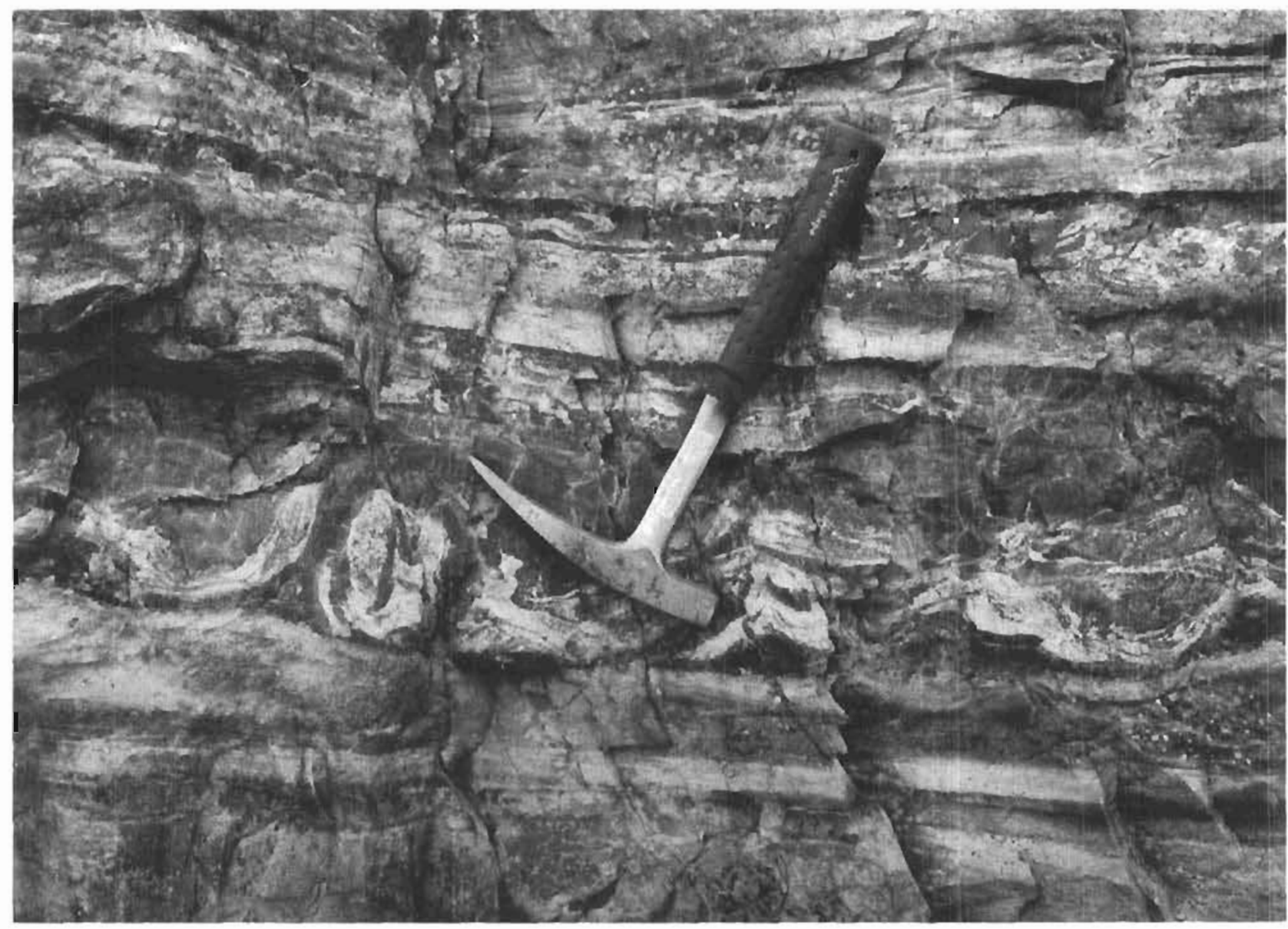

Figure 3. Soft-sediment deformation features in inlerbedded sandstone and siltstone of Toklik stratigraphic section.

ment. The presence of graded and finely laminated beds suggests deep-water turbidite deposition, Locally, solt. sediment deformation subsequent to deposition is indicated by crenulation of laminae.

Organic carbon ranged from 0.05 10 0.10 percelll in six samples tested. Thermal-alteration indices on visua] kerogen, which was dominated by herbaceous, woody, and amorphous lypes, ranged from $1+102$ for six samples analyzed. Porosicy ranged from 4.7107 .6 percent and permeability from 0.30 10 0.40 millidarcy for three samples irom this section.

\section{TOKLIK (LOCALITY 19)}

This stratigraphic section (pl. 3 ) is localed in sec. 30, T. 18 N., R. 68 W., and sec. 25. T. 18 N., R. 69 W., where interbedded silssione, nudsione, and minor sandsione, mapped as Gemuk Group by Hoare and Coonrad (1959b), crop out in the right bank of Yukon River (fig. 3). All lithologies are well indurated, and beds range from a few inches to several feet thick. Sandstone is very fine to fine grained, and many sandsione beds grade upward into siltstone. We interpret the rocks in this exposure 10 have been deposited by deep-marine iurbidity cursents.

Five samples were submitted for micropaleontological analysis. Threc of these were barren. Sparse Radiolaria and spicules in the other Iwo samples suggest deposition in an open marine environment bul are indeterninate of age. One sample submilted for palynological analysis was barren, but palynological analysis of a second sample suggested deposition in a marginal marine environment during Terliary cime. We believe these determinations are spurious and probably resulted from contamination of the sample.

Organic carbon sanged from 0.07100 .59 percent in seven samples tested. Thermal-alteration indices on visual kerogen, which was predominanlly herbaceous and woody, ranged from 2-10 $2+$ for these samples. Porosity ranged from 0.2 to 7.5 percent and pcrmeabilicy from 0.01102 .07 millidarcies in five samples from this section. Allother sample was fracsured and had a permeability of 6.31 millidarcies and a porosily of 5.5 percent.

\section{NELSON ISLAND 1 (LOCALITY 20)}

This stratigraphic section (pl. 4) is located along the west coast of Nelson lsland in sec. 28, T. 7 N., R. 89 W., and comprises mudstone and minor sandstone outcrops that were mapped as part of a graywacke-siltstone sequence of Cretaceous age by Coonrad (1957).

Well-preserved fossil leaves are common in the rocks of the section. Of six samples collected for palynological study, the ages of chree were indeterminate and three orhers 
indicale deposition during Albian lime. Deposition in marginal marine and probable nonnarine environments is also indicaled by the palynological samples. Seven micropalcontological samples were barren.

Seven geochemical samples contained from 0.07100 .38 pcrcent organic carbon and had thermal-alteration indices or 210 3- on visual kerogen, which consisted of woody. herbaceous, and coaly malerial. Two sandsione samplcs lested 2.8 and 7.2 percent porosity and 0.02 and 0.21 millidarcy permeability.

\section{NE.LSON ISLAND 2 (LOCALTTY 21)}

This stratigraphic section ( $\mathrm{pl} .5$ ) is located along (he west coasi of Nelson Island in sec. 31, T. 7 N., R. 89 W., where sandstone and mudstone similar to those of the preceding stratigraphic section crop oul (rig. 4). These rocks were mapped as part of the graywacke-sillstone sequence by Coonrad (1957).

Three samples collected for micropaleontological study were barren, but palynological siudy of three other samples indicalcd deposition in a marginal marine environment dur. ing Albian time. Geochemical analyses of three samples revealed 0.08100 .19 percent organic carbon with thermalalteration indices of 2 to $2+$ on visual kerogen, which was predominanily herbaceous, woody, and coaly. Five sandstone samples lested from 4.7 to 7.4 percent porosity and 0.04 to 0.50 millidarcy permeability.

\section{NUNIVAK ISLAND (LOCALITY 22)}

This siratigraphic section (pl. 6) is located along the north side of lookswarat Bay on the north coast of Nunivak Island in sec. 13, T. 3 N., R $100 \mathrm{~W}$., where silty mudstone, which contains concretionary zones and localized concentrations of carbonaceous debris and leaf and reed imprints, is interbedded with minor lenticular beds of sandstone with conglomeratic bases (fig. 5).

Palynological siudy of seven samples was indeterminate of age but suggested deposition in a nonmarine environment. Also, no age determination was possible for eight micropaleontological samples, but one of them contained fossils that suggest deposition in a marine environment.

Eight samples analyzed geochemically contained from 0.12100 .28 percent organic carbon. Thermal-alteration indices on visual kerogen. which consisted of woody, coaly, and herbaceous material, ranged from $2+104$ - for these samples. Four sandsione samples tested 2.2105 .6 percent porosily and 0.05100 .13 millidarcy permeability.

\section{GREAT RIDGE (LOCALITY 25)}

This stratigraphic section (pl. 7) is located along the crest of a spur perpendicular 10 the trend of Great Ridge in secs. 31 and 32, T, I S., R. 67 W. and secs. 34, 35, and 36, $\Upsilon$. I S., R. $68 \mathrm{~W}$, where interbedded sandstone, mudstone, and minor conglomerate, mapped as part of the Kuskokwim Group by Hoare and Coonrad (1959), crop out. Conglomerate beds are lencicular, and many sandsione beds are festoon cross-bedded. Well-preserved pelecypods are present in many mudstone beds and are abundane in two horizons.

Micropaleontological study of 17 samples was indeterminate of age, but two of these samples contained rossils

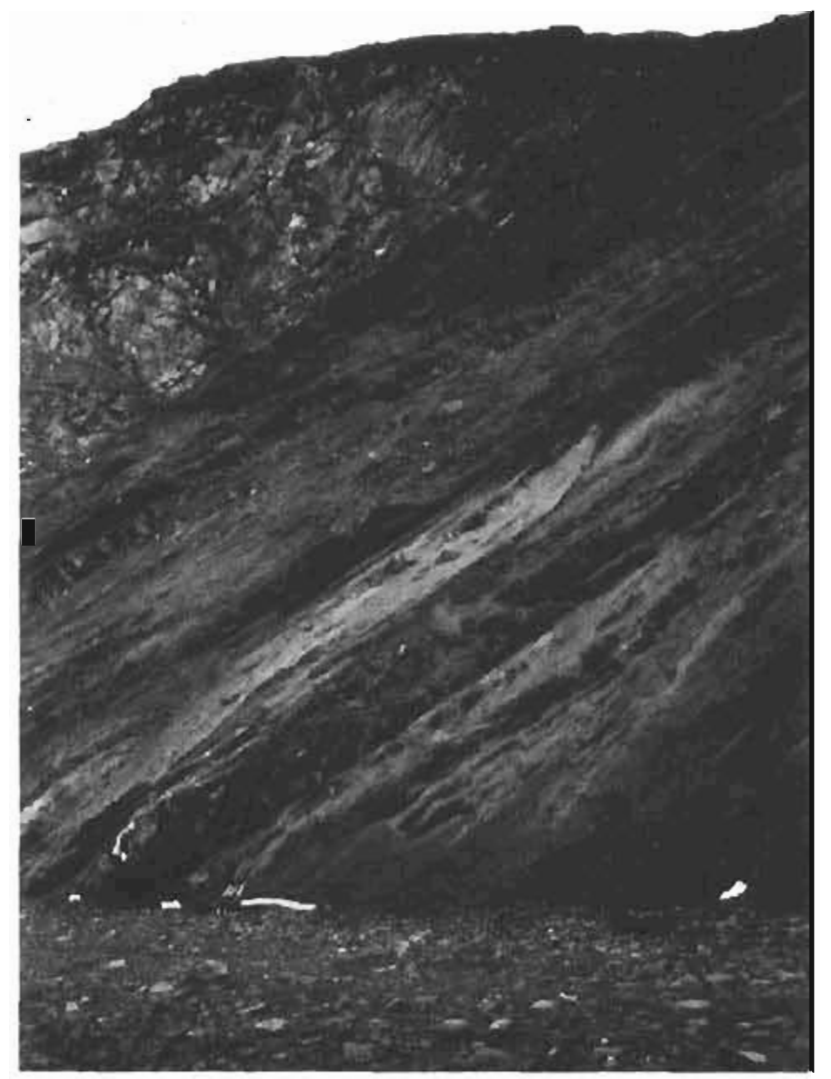

Figure 4. Nelson Island 2 stratigraphic section.

that suggest deposition in a marine environment. Palynological analysis of 14 samples suggested deposition in a nonmarine environment but was indeterminale of age.

Organic carbon ranged from 0.25101 .05 percent in 17 samples tested. Thermal-alceration indices on visual kerogen, which consisted of herbaceous, woody, and coaly material, ranged from 2- 10 3- for these samples. Twentynine sandsiorle samples tesied from 0.5 10 3.6 percent porosity and 0.02100 .24 millidarcy perneability.

\section{SPOT-SAMPLE DESCRIPTIONS}

Spot samples were collected 10 provide a wider distribucion of dala than could have been obtained by sampling only from measured stratigraphic secrions. In areas of poor exposure, samples were collected from rubblecrops, slumps, or frost boils. Locations, descriptions, and laboralory data for spol samples follow.

\section{LOCALITY}

Sample 39-GB-78 was collected in sec. 22, T. 9 N., R. $6 \mathrm{~W}$. on the north side of Mangoak River (fig. 6). The samplc is from one of several lenticular very fine sandy silt layers that are interbedded with 2-10 10-fool-thick silty, very fine to very coarse pebbly sand beds and 1- 10 6-lool-thick sandy gravel beds. Pebbles, cobbles, and boulders in these uncon- 
solidated sediments are almost exclusively rounded to wellrounded leucocratic granitic rocks. About 50 feet of moderately west-southwestward-dipping section is exposed. The hill in which the exposure is located is capped at its culmination west of the exposure with subhorizontal flow basalt; thick talus covers the lower part of the hill in that area, and whether the sediments are overlain by or adjacent to the basait was not determined. Patton and Miller (1968) considered ehese sediments to be of Tertiary age; our sample contained rare Laevigarosporiles $\mathrm{sp}$., which indicates Cenozoic age, and the dark color of this plant material, produced by thermal alteration, suggests a Tertiary rather than Quaternary age.

\section{LOCÀLTTTY 2}

Samples 43- to 45-GB-78 were collected in sec. $25, T .9$ S., R. $11 \mathrm{~W}$., where steeply dipping interbedded sandstone and siltstone crop out in the beach on the east side of Norton Bay. Sandstone is fine grained, grayish-orange lOYR $7 / 4$, and calcareous, and occurs in lenticular $1 / 2-104$-inch-thick beds. Siltstone contains some very fine sand, is moderatc yellowish-brown $10 \mathrm{YR} 5 / 2$, and occurs in $1 / 2$-inch-thick beds. Sample 45-GB-78, a sandstone, tested 2.7 percent porosicy and 0.07 millidarcy permeability. Testing of sample 44-GB-78, a siltstone, revealed an organic carbon content of 0.4$)$ percent and a thermal-alteration index on visual kerogen of $\underline{2}$ - to 2 ; herbaceous and woody material was abundant, and coaly material was rare among che visual kerogen. Palynological study of sample 43-GB-78 suggests a probable Neogene age for the rocks in this exposure, but the sparse assemblage on which that determination is based is very likely composed of contaminants from the modern environment. These rocks probably belong 10 the Shaktolik Group, which they resemble lithologically and siructurally and which has been mapped nearby by Cass (1959).

\section{LOCALITY 3}

Samples 54- to 57-GB-78 were collected in sec. 12, T, $15 \mathrm{~S}$, R. $12 \mathrm{~W}$. at the north end of a sea cliff in which steeply dipping interbedded sandstone and siltstone are exposed along the east end of Norton Sound between Beeson Slough and Blueberry Creek. In this area sandstone is the prevalent lithology. Sandstone beds are 6 inches to 10 feet thick and range in grain size from fine to coarse sand; individual beds are well sorted but may be graded near their bases, where streaks of poorly sorted sandsione are not uncommon. Some shale and siltstone rip-up clasts are present in the sandsiones. The sandsione is slightly calcareous and contains some calcareous concretions. Among these sandsione beds are a few laminated siltstone beds and some sequences of minor graded beds 1 to 3 inches thick. Two sandstone samples collected from this locality had porosities of 1.1 and 0.2 percent and permeabilities of 0.05 and 0.06 millidarcy. One sample, from a single 4-inch-thick black silty shale in which abundant coaly debris is visible, contained 4.3 percent organic carbon and had a thermat-alteration index on visual kerogen of $3+$. Woody and coaly material was abundant and herbaceous material common among the visual kerogen. The micropaleontological study of one sample was indeterminate of age, but the presence of rare Eponides(?) sp. suggests a possible marine environment of deposition. One sample was barren of palynomorphs.
These rocks have been mapped as part of the Shaklolik Group of Cretaceous age by Cass (1959).

\section{LOCALITY 4}

Sample 53-GB-78, a sandstone, was collected from the Shaktolix Group in a sea cliff in sec. 12, T. 17 S., R. 12 W., 1.6 miles south of Egavik. This sandstone tested 1.2 percent porosity and 0.05 millidarcy permeability.

\section{LOCALITY 5}

Samples 9- and 10-GB-78 were collected from a cutbank along Unalakleet River in sec. 1, T. 19 S., R. 11 W., where muddy fine sandstone, which Cass (1959b) mapped as part of the Shaklolik Group, crops out. This sandstone is dusky-yellow-green 5GY $5 / 2$ and contains abundant wellrounded black shale rip-up clasts. Abundant silty shale occurs as float in this area. The shale is olive-gray $5 Y 4 / 1$ and contains abundant carbonaceous plant debris locally. A sandstone sample tested 3.6 percent porosity and 0.30 millidarcy permeability. A shale sample, barren of paleontological material, contained 0.18 percent organic carbon with a thermal-alteration index of 3- to 3 on visual kerogen. which consisted of abundant woody and coaly material and common herbaceous macerial.

\section{LOCALITY 6}

Samples 13- and 14-GB-78 were collected from a cutbank along Unatakleet River in sec. 4. T. 19 S., R. 10 W., where interbedded sandstone and shale, which were included in the Shakiolik Group of Cretaceous age by Cass (1959b), crop oul. Sandstone, which is the predominant litholoby, is medium-gray N5, silty, fine grained, calcareous, and contains shale rip-up clasts locally. The shale is dark-gray N3 and silty. A sandstone sample tested 2.0 percent porosity and 0.08 millidarcy permeability. A shale sample contained 0.21 percent organic carbon with a thermal-alteration index of $3-103$ an visual kerogen, which consisted of abundant herbaceous material and common woody and coaly marerial; this sample was barren of paleontological material.

\section{LOCALITY ?}

Samples 11- and 12-GB-78 were collected from a cutbank along Unalakleet River in sec. 36, T. 18 S., R. 10 W., where interbedded sandstone and shale, mapped as belonging to the Shaktolik Group by Cass (1959b), crop out. The sandstone is light-olive-gray $5 Y 5 / 2$ and fine 10 medium grained with some pebble-size shale rip-up clasts locally. The shale is dark-gray N3 and silty. A sandstone sample lested 2.1 percent porosity and 0.09 millidarcy permeability. A shaje sample, which was barren of paleontological material, contained 0.61 percent organic carbon and had a thermalalteration index of $210 \underline{2}+$ on visual kerogen, which included abundant herbaceous, woody, and coaly material.

\section{LOCALITY 8}

Samples 7- and 8-GB-78 were collected from a cutbank along Unalakleet River in sec, 8, T. 18 S., R. 8 W., where interbedded silty shale, siltstone, and silty fine sandstone 


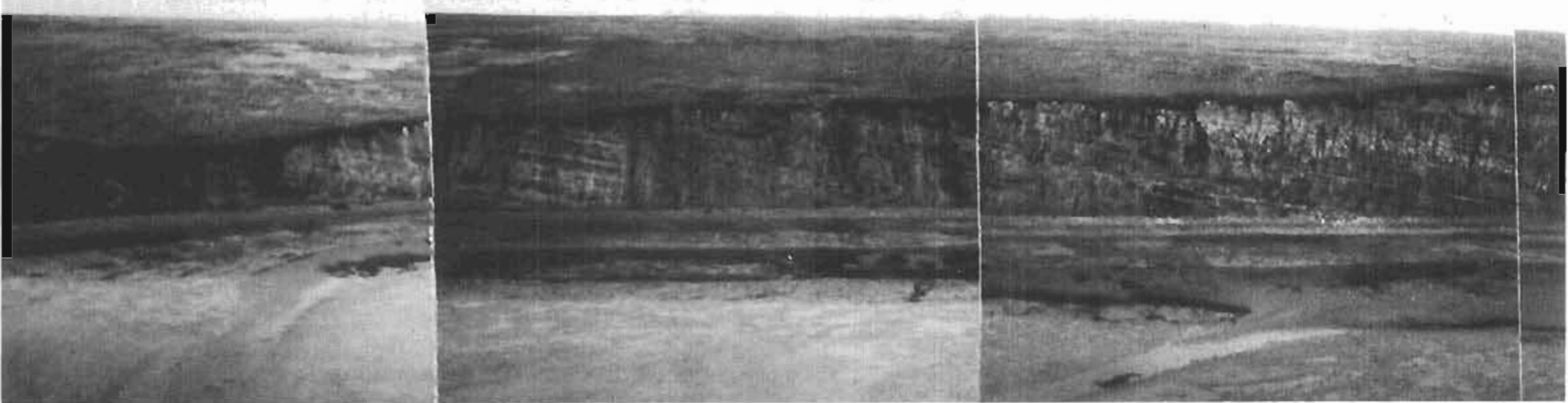

crop out. These rocks were included in the Shaklalik Group by Cass (1959b). The sandsione is medium-lighl-gray N6. slightly calcareous, weakly laminated, contains shale parlings locally, and is in 3-10 6-foot beds. Conlacis belween sandstone and shale are gradalional, effecled by an increase in number and thickness of shale partings. The shale is dark-gray $\mathrm{N} 3$ and noncalcareous. The siltslone, which comprises abous 75 percenc of the oucrop, is dark-gray N3. muddy, and laminated. A sandstone sample lested 2.2 per- cent porosily and 0.14 millidarcy permeability. A shale sample, barren of paleontological material, contained 0.18 percent organic carbon and had a thermal-alteration index of 3-10 3 on visual kerogen. which included abundant woody and coaly malerial and common herbaceous material.

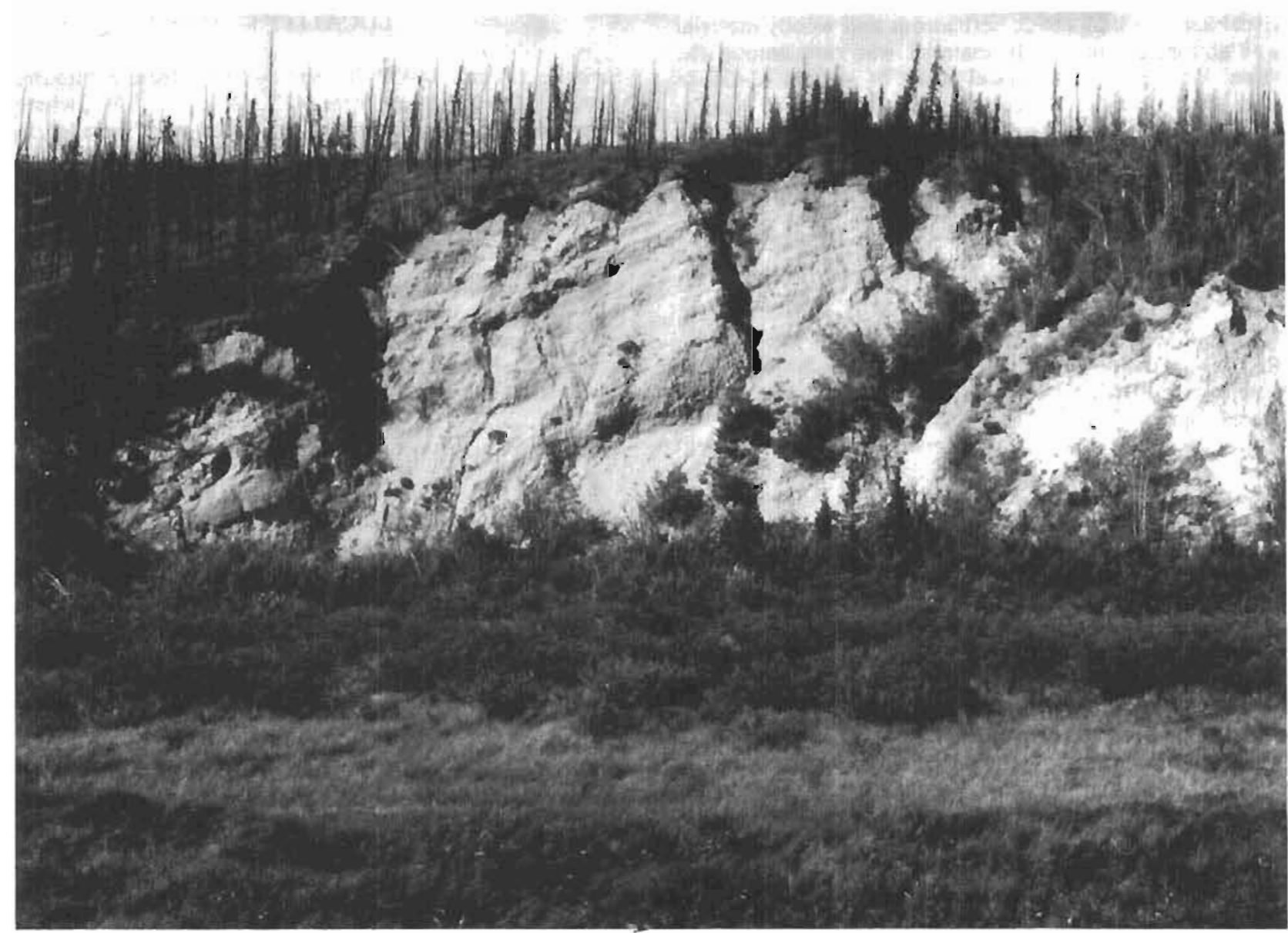

Figure 6. Outcrop of unconsolidated gand and gravel at locality 1 along Mangoak River. 


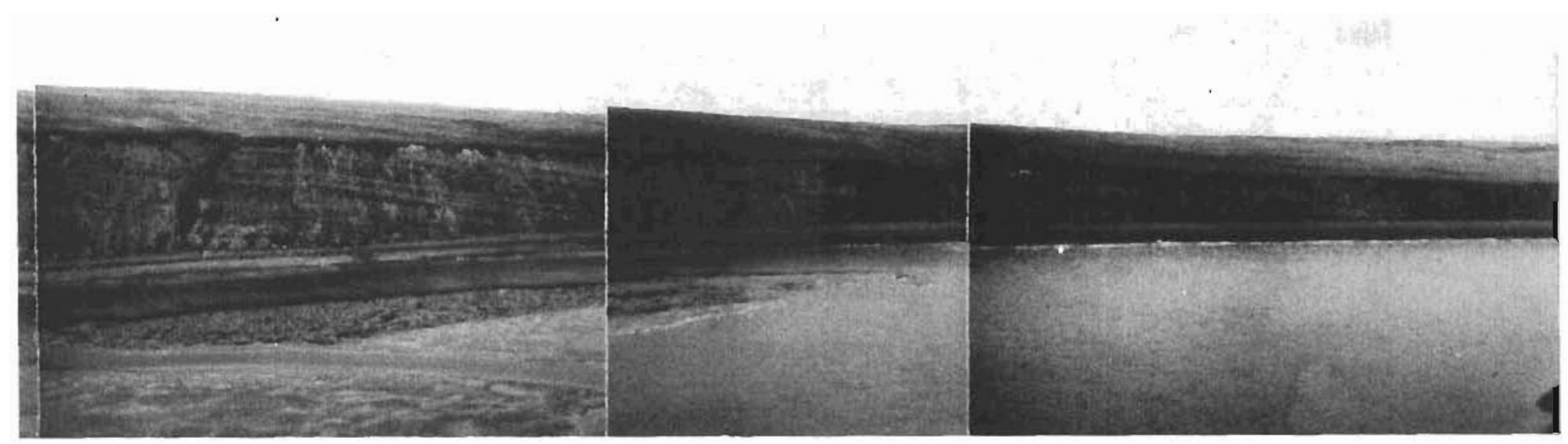

\section{LOCALITY 9}

Samples 32- 10 35-GB-78 were collected from the beach south of Unalaklect between Cascade and Clacier Creeks in scc. 28, T. 20 S., R. II W., where Roat blocks' of lithologies unlike the Shaklolik Group, which dominates local exposures, occur logether with coalifsed wood fragments in solifluction lobes. Coalificd wood fragments are commonly associated with light-olive-gray SY $6 / 1$ fine sandstonc, which contains scaftered coarse sind and granule grains (fig. 7); this sandstone also occurs in small fragmenis without associated coal. Thin-bedded finc sandstone of greenish-gray 5G 6/I color occurs in large blocks and was nor observed in association with coal. Sandsiones are very weakly indurated. Medium-yelluwish-brown 10YR $5 / 2$ sardy mudstone with abundarll carbonaceous plant debris comprises a third lithology presint in lhe hoal. A sample of the sandstone associated wich the coal tested 6.9 percent porosity and 48 millidarcics permicability: a sample of the thin-bedded sandslone lested 6.1 percenl porosily and 1.49 millidarcies permeability. Palynological study of a mudstone sample indicaled Neogene age and deposition in a nonmarine environment. Arralysis or a coal sample at the Department of Energy's Pittsourgh (col Laboralory indicaled high volatile $C$ bituminous grade with a heating value of $11.350 \mathrm{Btu} / \mathrm{Ib}$ on a moisl. asli-free basis.

\section{LOCALITY 10}

Samples 29- and 30-GB-78 were collccied from a sea cliff at the sourh side of the moutl of Glacier Creek in sec. 33, T. 20 S., R. II W, where sleeply dipping incerbedded sandslone arid shale crop out. These outcrops were included in the Shaktolik Group by Cass (1959b). Sandsione occurs in 2- 10 15-inch beds and is medium-gray NS, silly, fine grained, and laminated. Locally abundam shalc parlings define a cross-lamination in the sandstorte. Shale is siky. occurs in $1 / 2$-inch-10 3-fool beds, is dark-gray N3, and has hackly l'raclure. Sandsione and shale are of subequal abun. dance in this area. A sandstone sample tested I.2 percent porosity and 0.08 millidarcy permeability. A shale samuple contained 0.38 percent organic carbon witls a thermalalteration index of 3-10.3 on visual kerogen, which consisted of abundant woody and coaly material and common herbaceous material; the sample was barren of palconcological macerial.
Figure 5. Panoramic view of Nunivak Lsland stratigraphic section.

\section{LOCALITY 11}

Samples 24- 10 28-GB-78 were collected from a sca clilf at the south side of the mouth of Spruce Creck in sec. 13, $T$. 2) S., R. $12 \mathrm{~W}$, where steeply dipping interbedded shalc. siltstone, and sandstone, which Cass (1959b) included in the Sliaklolik Group, crop ou, Shale is dark-gray N3; silıstone contains some very fine sand, is medium-dark-gray N4, and has noncélcareous concrelions along bedding surfaces. Shale and silısione are laminated and contain minor plant debris and coal fragmens and stringers. Sandstone is a minor lichology in this outcrop; it is cross laminated, very fine 10 medium grained, and medium-lighl-gray N6 with shale rip-ups and partings. Individual shale and siltstonc beds ringe from $1 / 2106$ inchen in thickness, and sandsione beds may bi as thick as $3 \mathrm{fect}$. A sandstone sample tested 8.1 percene porosity and 0.12 millidarey permeability. A sluale sample was not datable by palcontological tecliniques but contained rare echinoid fragments suggestive of a marine depositional environment. Anorher shale sample containcd 0.37 percenl organic carbon with a thermalalteration index of $3-103$ on visual kerogen, which consisted of abundant herbaccous, woody, and coaly material. Analysis of a coal sample al the Depariment of Energy's Pitısburgh Coal Laboratory indicaled semianthracitc grade wilh 86 percent fixed carbon on ad dry, ash-iree basis

\section{LOCALITY 12}

Samples 22. and 23-GB-78 were collecied from a hill at Point Romanof in sec. 34. T. 26 S., R. 22 W., where inrerbedded sandsione and silisione crop out. These exposures have been mapped as Cretaceous calcareous sandslone by Hoare and Condon (197I), and we consider them part of the Shaktolik Group. Siltstone in this outcrop is olive-gray $S Y 4 / 1$, laminated, muddy, and calcarcous; sandstone is fine grained, medium-greenish-gray 5GY 5/I, silty, slightly calcareous, and contains shale partings locally. One sandstone sampic tested 2.9 percent porosity and 0.08 millidarcy permeability. A siltstone sample contained 0 . I0 percent organic carbon with a thermal-alteration index of $2102+$ for visual kcrogen, which included abundant woody and coaly material and conimon herbaceous material. One sample was barren of paleontological macerial. 


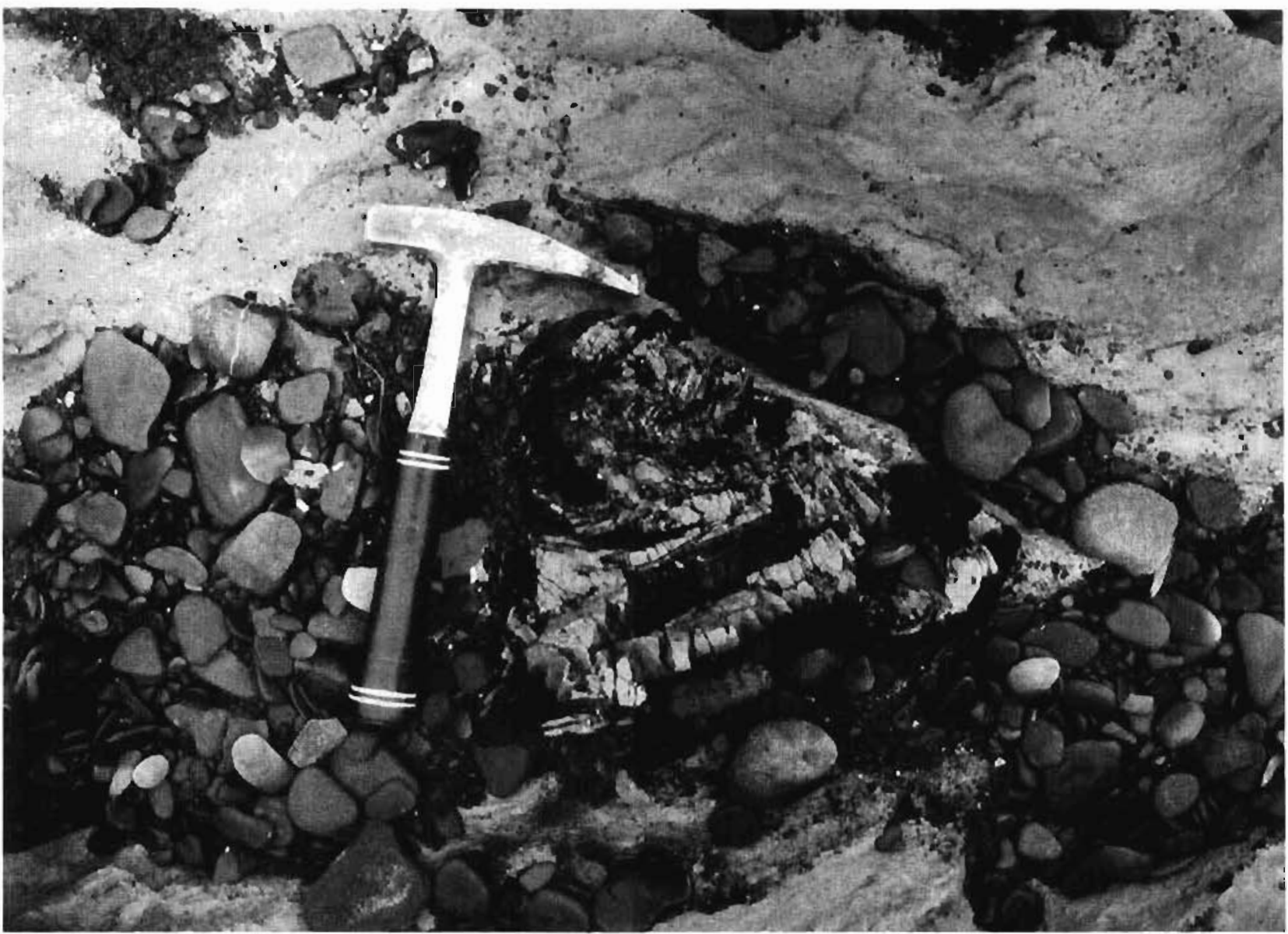

Figure 7. Coal and sandstone of Tertiary age in soliflucation lobe at locality 9 on the beach south of Unalakleet.

\section{LOCALITY 13}

Samples 2- and 3-GB-78 were collecied from a cutbank along Nunakogok River in sec. 32, T. 27 S., R. 19 W., where intcrbedded medium-dark-gray N4 hine sandsione and grayish-black siliceous shale crop out. These exposures have bcen mapped as Crelaceous noncalcareous sandsione by Hoare and Condon (1971), and we include them in the Shakcolik Group. Sandstone beds range up to 3 leet lhick. and shale beds range up to 25 feet thick. A sandsione sample tcsed 2.5 percent porosity and 0.15 millidarcy permeability. A shale sample was barren of paleontological material but contained 0.45 percent organic carbon with a thermal-alteration index of $3103+$ on visual kerogen, which included abundant woody and coaly material and rare herbaceous material.

\section{LOCAl,ITY 14}

Samples 17- 10 20-IP-78 and 28- and 29-TF-78 were collecled in the Kuzilvak Mounlains in sec. 30, T. 22 N., R. 83 W. Sample 24-TF.78 was collecied from a frosi boil; the olher samples were collected from rubblecrop. Medium. dark-gray N4. faintly laminated, very well indurated calcareous fine sandsione and dark-gray N3 silly shale, which were mapped as noncalcareous sandsione of
Crelaceous agc by Hoare and Condon (1971), were present Three sandstone samples tesled from 0.2 to 0.04 percent porosily and from 0.05 to 0.06 millidarcy permeability; a fourth sandscone sample, which is quite similar to the other sandstone samples lithologically, iested 4.9 percent porosily and 0.01 millidarcy permeability. Two shale samples conlained 0.10 and 0.29 percellt organic carbon and had thermal-alteration indices of 4-10 4 for visual kerogen. which was predominantly herbaceous. No palcontological samples were collected at this locality.

\section{LOCALITY 15}

Samples 50- 10 52-GB-78 were collected from the right bank of Yukon River 0.2 mile west of Old Andreafsky in sec. 21, T. 23 N., R, 77 W., where steeply dipping incerbedded sandstone and shale, which were mapped as laumontitized sandstone of Crelaceous age by Hoare and Condon (1966), crop out. We consider these exposures par of the Shakcolik Group. Sandsione is graded from pebbly fine 10 coarse grained to silty shale, is locally calcareous, contains some shale rip-ups, and commonly has load realures at the base of beds; coarser sandstone beds are olive-brown 5 Y $5 / 1$. Shale is silty, grayish black N2, and coninins sone carbonaccous plant debris. A few calcarcous concretions occur in both the sandstone and the shale, and some primary 
slump features, including disharmonic folds and sand rolls, were observed in this outcrop. A coarse sandstone sample lested 0.4 percent porosity and 0.05 millidarcy permeabili$1 y$, and a fine sandstone sample tested 5.1 percen porosity and 2.04 millidarcies permeability. A shale sample, which was not datable by paleontological techniques, contained rare Cibicides sp. and Cenosphaera spp., which suggests deposition in a marine environment. The sample contained 0.17 percent organic carbon with a thermal-abteration index of $2+103-$ on visual kerogen, which consisted of abundant woody and coaly material and rare herbaceous material.

\section{LOCALITY 16}

Sample 49.GB-78 was collected from the top of a hill 1 mile west of St. Mary's airport in sec. 25, T. 23 N., R. 77 W., where a subhorizomal sandstone mapped as calcareous sandstone of Cretaceous age by Hoare and Condon (1966) crops out. We consider this exposure part of the Shaktolik Group. This sandstone is flaggy, gritty, fine to coarse grained, calcareous, and medium-gray N5. The sample tesled 7.2 percent porosity and 1.76 millidarcies permeability.

\section{LOCALITY 17}

Samples 47- and 48-GB-78 were collected from a quarry at the crest of the road across Andreafsky Mountain between St. Mary's airport and St. Mary's village in sec. 29, T. 23 $\mathrm{N}$, R. $76 \mathrm{~W}$., where overturned, interbedded sandstone and shale, which have been mapped as noncalcareous sandstone of Crelaceous age by Hoare and Condon (1966), crop out. We consider thesc outcrops part of the Shaktolik Group. The stratigraphically lowest unit in this exposure is a massive, medium-dark-gray N4, fine sandstone 4 to 6 feet thick, which contains aburdant well-rounded cobble- to small boulder-size shale rip-ups and has load features on its basc. Stratigraphically above this massive sandstone is a 60-foot section of 2-to 15-inch cross-laminated beds that grade from very fine sandstone al their bases 10 siltstone at their tops. The sandstone is medium-dark-gray N4 and the silssione is dark-gray N3. These graded beds contain well. rounded cobble- to small boulder-size shale rip-ups and some burrows and commonly have load features on their bases. The graded beds are stratigraphically overlain by dark-gray N3 siluy shale. Caicareous cannonball concretions are common in the sandstone, and flattened concre. tions are common in the shale. Carbonaceous plant debris is also common. A sandstone sample tested 0.9 percent porosity and 0.07 millidarcy permeability. A shale sample, which contained insufficient paleontological material for determination of age or depositional environment, contained 0.39 percent organic carbon with a thermal-alteration index of $2102+$ on visual kerogen, which consisted of abundant woody and coaly material and common herbaceous material.

\section{LOCALITY 23}

Samples 66-10 68-IP-78 were collected from a small outcrop at the southwest corner of Nash Harbor in sec. 2, T. I N., R. $103 \mathrm{~W}$., on Nunivak Island. These samples were mapped as part of a graywacke-siltstone sequence of Cretaceous age by Coonrad (1957) and consist of hard, black NI, splintery shale. One sample contained 0.54 percent organic carbon and had a thermal-alteration index of 4- to 4 on visual kerogen, which consisted of abundant woody and coaly material ano common herbaceous material. A sample collected for micropaleontological analysis was barren, but another sample contained a sparse palynomorph population that was indeterminate of age and indicated a probable nonmarine depositional environment.

\section{LOCAYITY 24}

Samples 63- 10 65-IP-78 were collected from a small oul. crop overlain by volcanic flows along the southern shore of Nash Harbor in sec. 5. T. I N., R. 102 W., on Nunivak Island. These samples were mapped as part of a graywackesiltstone sequence of Cretaceous age by Coonrad (1957) and consist of hard, grayish-black N2 mudstone that exhibils hackly fracture. A gcochemical sample contained 0.87 percent organic carbon and had a thermal-alteration index of $3+$ to 4 - on visual kerogen, which consisted of abundant woody and coaly material with minor herbaceous material. A micropaleontological sample was barren, but another sample contained pollen suggestive of Cretaceous age and deposition in a marine environment.

\section{LOCALITY 26}

Samples 20-, 21-, and 23- to 26-TF-78 werc collected from an outcrop along a ridge crest in the northern part of the Eek Mountains in sec. 5, T. 1 S., R. $64 \mathrm{~W}$, These samples are of gray mudstone and pebble to cobble conglomerate in which quartz., andesite, and green mudstone constitute the majority of clasts. The exposure was mapped as conglomeratic facies of the Kuskokwim Group by Hoare and Coonrad (1959). Two sandstone samples contained 0.52 and 0.16 percent organic carbon and had thermal-alteration indices of $2102+$ and $3+$ on visual kerogen, which consisted of abundant woody and coaly material with ninor herbaceous material. One palynological and three micropaleontological samples were barren.

\section{LOCALITY 27}

Samples 31-and 32-IP-78 were collected along the north side of Kagati Lake in sec, 28, T. 3 S., R. 63 W. from an outcrop mapped as Gemuk Group by Hoare and Coonrad (1961). These samples are of well-indurated, medium-darkgray N4 siltstone. One sample tested 1.9 percent porosity and 48 millidarcies permeability, but these values may be unrepresentatively high because of the presence of horizontal fractures. The other sample contained 0.14 percent organic carbon with a thermal-alteration index of 2 to $2+$ on visual kerogen, which consisted of abundant woody and common herbaceous malerial.

\section{LOCALITY 28}

Samples 21- 10 30-1P-78 were collected from the top of a hill in sec. 12, T. 4 S., R. 64 W., where rock mapped as Gemuk Group by Hoare and Coonrad (1961) erops out. Lithologies exposed at this location include well-indurated, light-olive-gray $5 Y$ 5/2, fine to medium sandstone; wellindurated dark-gray N3 10 grayish-black N2 argillite (which is generally thin bedded and locally cherty); and brecciated, 
dark-gray N3 micrite. A sandstone sample tested 2.1 percent porosity and 0.07 millidarcy permeability. Two geochemical samples contained 0.06 and 0.07 percent organic carbon with thermal-alteration indices of 3 to $3+$ on visual kerogen, which consisted of abundant herbaceous with lesser woody and coaly material. Palynological examination of rwo samples was indeterminate of age or depositional environment, and one micropaleontological sample was barren. A sparse foraminiferal ponulation in another sample was indeterminate of age, but a prc bacie marine depositional environment was indicated.

\section{PETROGRAPHY}

Seventy-four samples from measured siratigraphic sections and spol localities were studied petrographically. Eleven samples were from the Gemuk Group in the Yukon River and Toklik stratigraphic sections and the Kagati Lake area. Thirty were from the Kuskokwim Group in the Great Ridge stratigraphic section. Sixteen were from the Shaktolik Group in the area between St. Marys on the Yukon River and Koyuk on Norton Bay. Fifteen samples were from outcrops of undifferentiated Cretaceous rocks in the Nunivak Island and Nelson Island I stratigraphic sections and the Kuzilvak Mountains area. The remaining two were from an exposure of Tertiary rocks south of Unalakleet.

Framework clasts in alt the samples are predominantly lithic or quartzose grains. Samples from younger rock units tend to be more quartzose than samples from older rock units. Framework grains from Gemuk Group samples are composed primarily of lithic fragments (63 1085 percent) and contain less than 7 percent quartzose clasts. Framework clasts in samples from the Shaktolik and Kuskokwim Groups contain from 8 to 68 percent quartzose grains, among which cherl is quite common in the Kuskokwim Group samples. Feldspar ranges from 16 to 35 percent of the framework clasts in samples from the Shaktolik Group but does not exceed 17 percent in any of the Kuskokwim Group samples. The framework clast compositions of samples from exposures of undifferentiated Cretaceous rocks partialty overlap the framework clast compositions of samples from the Gemuk, Kuskokwim, and Shakrolik Groups. A maximum of 37 percent of the framework clasis in the undifferentiated Cretaceous samples are quartzose, whereas lithic grains make up at least 56 percent of the framework clasts in these same samples. The two Tertiary samples contain at least 70 percent quartzose grains, 21 percent lithic grains, and no more than 9 percent feldspar among their framework clasts. Framework clast compositions for 20 samples for which point counts were made are presented as figure 8 and in rable 7.

Quartzose grains are primarily monocrystalline with straight to moderately undulatory extinction in the samples from the Gemuk Group, but schistose polycrystalline quartz grains are common in the Shaktolik Group, Kuskokwim Group, and Tertiary samples, and chert grains are common in Kuskokwim Group samples.

Plagioclase is the principal reldspar in all the samples. Intermediate plagioclase, which is generally twinned according to the albite law and zoned and variably unaltered to moderately kaolinitized or sericitized, is common in all the samples and is the only feldspar observed in the Gemuk
Group samples. Untwinned albite is common in the Shakiolik Group samples, Kuskokwim Group samples, and the Tertiary samples and is the predominant feldspar in many such samples.

The lithic fraction of framework clasts in Gemuk Group samples consists of vitrophyric, intersertal, and holohyaline volcanic grains; spherulitic and perlitic textures are developed in some holohyaline grains. In addition to holohyaline and hypocrystalline volcanic rock fragments, the lithic fractions of samples from the Shaktolik Group. Kuskokwim Group, and Teriary contain holocrystallinc volcanic rock fragments, mudstone grains, silestone grains, and quartz-muscovite schist grains.

Framework clasts range from subangular to subrounded in Gemuk Group samples, from subangular to rounded in Shaktolik Group samples, from subangular 10 well rounded in Kuskokwim Group samples, and from angular to rounded in Tertiary samples. There is no apparent correlation between clast type and degree of roundness in any of the samples. Grain shapes in all the samples, excep! possibly sandy limestones, have been modified by ductile grain deformation attendant on compaction. Grain boundaries between volcanic rock fragments in Gemuk Group samples have commonly been obscured so that nondelimited volcanic clasts form a pseudomatrix in the samples.

it is evident from the types of framework clasts that the Gemuk Group samples were derived from a predominantly volcanic source terrane and that the other samples were derived from more varied source terranes in which sedimentary and metamorphic as well as volcanic rock types were abundant. A significant admixture of recycled sedimentary detritus is especially evidenced by the well. rounded quartz clasts in many Kuskokwim Group samples. The variability in and lack of correlation of roundness and grain type among framework clasts in samples from the Shaktolik Group, Tertiary, and undifferentiated Cretaceous exposures also suggest that clasts were recycled from older sedimentary sources.

Iron oxide, leucoxene, carbonate, clays, plagioclase, quartz, and zeolites were observed authigenic phases in the samples. Authigenic plagioclase was observed only in Gemuk Group samples, where it constitutes an early veinfilling material. Carbonate and authigenic quartz are pre. sent only as vein-filling phases in Gemuk Group samples. Iron oxide, clay, and zeolites are dispersed authigenic phases in the samples from the Gemuk Group. Iron oxide is present as a coating on clasts, and clay is present as an intergranular material and as an alteration product in clasts. Laumontite is the most common zeolite in Gemuk Group samples and appears to be present as a general replacement of clasts and intergranular material; other zeolites are presem in some nonlaumontitized Gemuk Group sampies as filling in intergranular spaces. Zeolite in intergranular spaces is invariably separated from clasts by clay, thus the clay is older than the zeolite.

Iron oxide, carbonate, clay, and quartz are present as authigenic phases in samples from the Shakcolik Group, Kuskokwim Group, and Tertiary and undifferentiated Cretaceous exposures. Zeolite is present in some Shakiolik Group samples. Carbonate is present as a replacement and as an intergranular cemeni, but the other authigenic materials appear to be present only as cements. Autbigenic quartz is syntaxial to adjacent quartz clasts and generally 


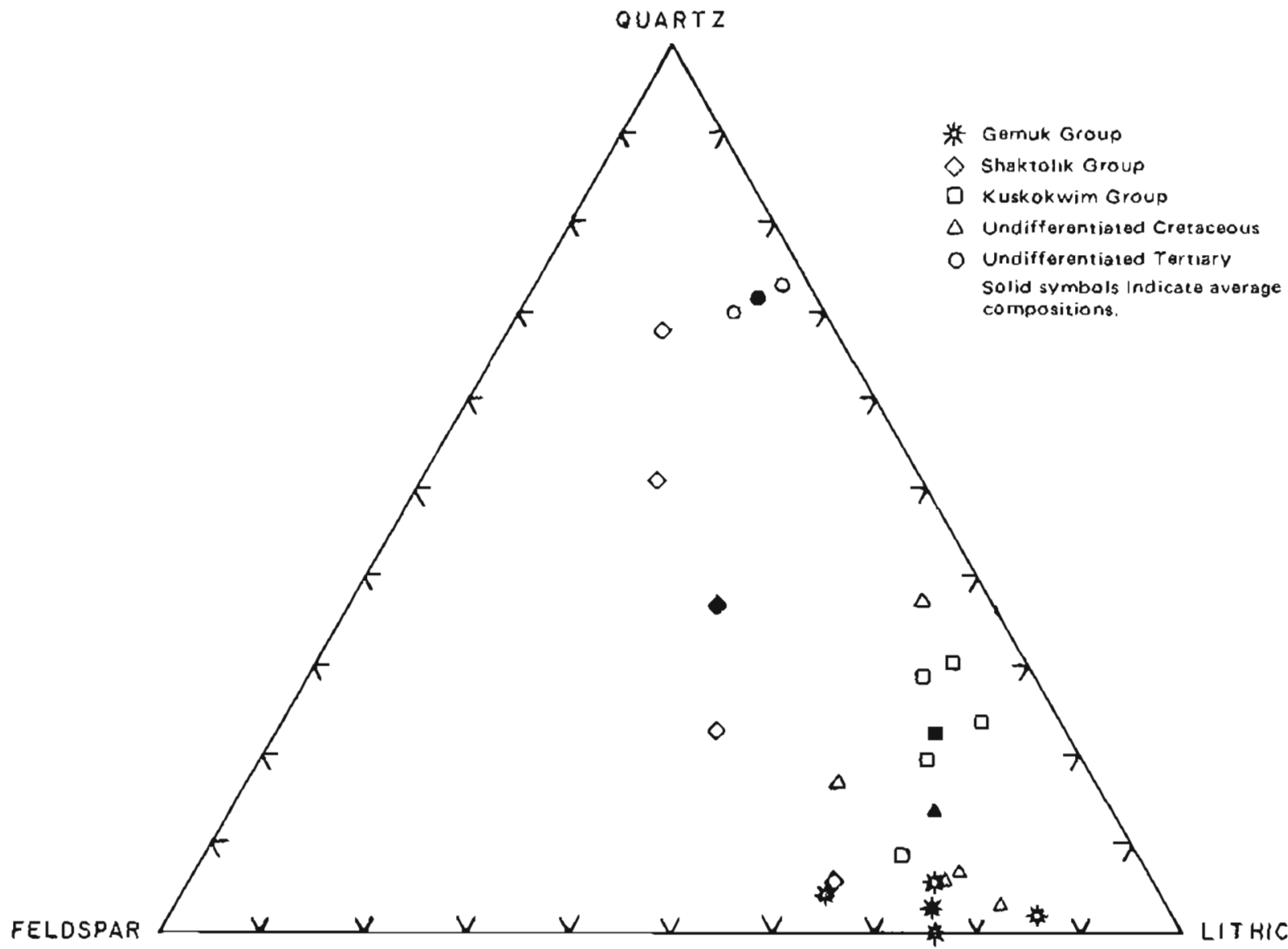

Figure 8. Framework grain compositions of point-counted sandstone samples from southwestern Alaska.

separated from them by a partial coat of authigenic clay. Iron oxide is the oldest and quartz or zeolite the youngest authigenic phase in the samples; where carbonate and authigenic clay are both present, carbonate is older. The amount of carbonate cement and degree of ductile grain deformation are inversely proportional; thus, carbonate cementation must have begun early in the burial of the rocks.

No visible porosity was observed in any of the samples. Inhomogeneity of packing, oversized and elongate intergranular areas, and floating and fractured clasts in the Shaktolik Group, Kuskokwim Group, and 'Tertiary samples suggest that authigenic cements may be filling secondary pores. Intergranular laumontile is inhomogeneously distributed in oversized areas that contain floating grains in Gemuk Group samples, but the common nebulosity of its contacts with pseudomatrix suggests a replacement origin without prior development of secondary porosity. The rock units as seen in the samples have little potential as petroleum reservoirs except in areas where extensive fracture porosity might exist. However, the probable past existence of secondary porosity in all rock units sampled except the Gemuk Group suggests that under appropriate subsurface conditions sufficient intergranular porosity for a petroleum reservoir might exist in the post-Gemuk Group rocks examined in this study.

\section{CHARACTERISTICS OF POTENTIAL RESERVOIRS}

\section{GEOMETRY}

Stratigraphic-section and spot-sample localities are widely separaled geographically, and it is not surprising that rocks from the various localities were deposited in different environments or thal potential reservoir sandstones are characterized by different geometries.

The Gemuk Group and much of the Shaktolik Group are characterized by rhythmically bedded sandstone, siltstone, and mudstone typical of deep-water turbidites. Sand bodies associated with turbidite deposition are commonly arrayed in channels, lobes, and sheets. Channeis and lobes are generally associated with submarine fans, but sheet deposits can extend over a basin plane and may nol be associated with any fan.

Submarine fan channels are many limes as long as they are wide and several times as wide as they are thick. Sediment trassport is generally through single, large channels near the apices of fans, bul such channels grade to braided systems of smaller channels away from the apices. Potential reservoir sandstones deposited in channel environments will be elongated in direction generally normal to the depositional strike. 
Most of the coarser sediment coming through fan channels is deposited in lobes that are located at the ends of the channels. Shale beds, which form part of most classical turbidite sequences, are generally nol present. A typical submarine fan lobe may be about 15 miles in diameter and 300 reet thick (Walker, 1978).

Sheet turbidite sandstone beds may extend over a large area, but are generally onty a few inches thick and separaled from each other in vertical sequence by equally extensive shale beods. Basin-plain sheet turbidite sandstone beds may merge into lobes laterally.

The Kuskokwim Group, part of the Shaktolik Group, and the undifferentialed Cretaceous and Tertiary rocks examined were depossted in shallow marine and nonmarine environments. Fluvial channel sandstones, which display elongate meandering morphologies, are present in the nonmarine parts of these rock units, and such channel sandstones are generally elongate normal to the depositional strike and paleoshoreline. Shallow-marine sandsiones in these rock units may be expected to have the tabular geometry lypical of sand bodies deposited as beaches, offshore bars, barrier islands, and spits. Widths of such tabular bodies are commonly 50 to 1000 times their thicknesses (Krynine, 1948).

\section{QUALITY}

Seventy-two samples were analyzed for porosity and permeability (table 4). Porosities ranged from 0.2 to 8.1 with an average of 2.9 percent. However, if two fractured samples with permeabilities of 6.31 and 48 millidarcies and a Tertiary sample with a permeability of 48 millidarcies are excluded, permeabilities sange from 0.01 to 2.07 with an average of 0.19 millidarcy. These values are all very low.

\section{HYDROCARBON SOURCE ROCKS AND BASIN MATURITY}

A total of 69 samples were processed for C $15+$ soxhlet extraction and dessphalteaing by Geochem Laboratories, Inc. Table 3 shows a listing of these samples. When the nonhydrocarbons (precipitated asphaltene and nitrogen, sulfur, and oxygen compounds) are subtracted from the total extract, nor a single sample contained more than 300 ppm hydrocarbons, the generally accepted threshold level for a petroleum source rock. The extracted hydrocarbons ranged from 6 to $99 \mathrm{ppm}$ and averaged $48 \mathrm{ppm}$. Fifty-eight samples were not processed for complete liquid chromatography because of the lean amount of nC5 soluble in the C15 + total solvent extractable bitumen.

Except for one sample, organic carbon ranged from 0.05 to 1.05 percent; only 13 samples contained more than 0.5 percent carbon, the normally accepted minimum organic carbon threshold level for hydrocarbon source rocks. The one sample with highes organic carbon content was from the Shaktolik Group south of Beeson Slough and about 20 miles north of Unalakleet. It contained an exceptionally high value of 4.3 percent organic carbon and was taken from a unique and very thin bed.

In general, the suite of samples processed indicates that the hydrocarbon source-rock potential is very low in areas adjacent to the sampling sites. Many of these data are from coastal exposures and tend to downgrade the adjacent OCS area with respect to hydrocarbon source potential.

Visual kerogen in the 69 geochemical samples collected ranged from $1+104$ in thermal-alteration index; most sampies were in the $2-103+$ range (table 2). This range is considered to be representative of the ability of the kerogen to produce either "wet" or "dry" associated hydrocarbons, depending on kerogen type. Kerogen in the samples is overwhelmingly dominated by herbaceous, woody, and coaly material; thus, generated hydrocarbons are expected 10 be "dry" and gaseous. However, the sparseness of the organic content indicates only a slight possibility of the occurrence of any commercial hydrocarbons adjacent to the sampling sites.

\section{CONCLUSIONS}

Tabular deep-and shallow-marine and elongate marine and nonmarine sand bodies, some of which exceed 100 feet in thickness, are common in the ourcrops examined. Similar sandstone bodies should exist in the adjacent offshore areas of Norton Sound and Kuskokwin Bay. However, the low reservoir quality that has resulted from diagenetic changes in the sandstone samples studied suggests that potentially productive levels of porosity and permeability in their of fshore equivalents depend on the existence of secondary porosity. The task in predicting the locations of potential reservoirs in such offshore equivalents is more a matter of delimiting where secondary porosity may have developed and been preserved than of locating sand bodies.

Although thermal-alteration indices indicate that most of the geochemical samples are in the upper immature to malure range of thermal maturity and therefore capable of having generated hydrocarbons, the amount of organic carbon present in most of the samples was less than the 0.5 percent normally considered the minimum threshold level for hydrocarbon source rocks. Because the overwhelming majority of visual kerogen in the samples comprises "dry" gas precursors, the beds sampled are most likely to have produced only minor, noncommercial amounts of "dry" gas. Of course, different types and greacer amounts of organic material may have collected in rocks in submerged lands adjacent to the study area, but our work onshore does not give cause for optimism.

In summary, the discovery of hydrocarbons in commercial quanticies in the Norton Sound-Kuskokwitn Bay area depends on the existence of potential reservoir and source rocks of better quality in offshore areas than are present onshore. However, very little of the Teriary fill in the offshore basins is exposed onshore; thus, a sizable part of the stratigraphic column in the offshore basins was not tested in this study.

\section{REFERENCES CITED}

Cady, W.M., Wallace, R.E., Hoare, J.M., and Webber, E.J., 1955, The central Kuskokwim region, Alaska: U.S. Geological Survey Professional Paper 268, $132 \mathrm{p}$.

Cass, J.T., 1959a, Reconnaissance geologic map of the Norton Bay Quadrangle, Alaska: U.S. Geological Survey Miscellaneous Geologic Investigations Map I-286, scale $1: 250,000,1$ sheet. 
Cass, J.T., 1959b, Reconnaissance geologic map of the Unalakleet Quadrangle, Alaska: U.S. Geological Survey Miscellaneous Geologic Investigations Map I:288, scale l: $250,000,1$ sheet.

Coonrad, W.L., 1957. Geologic reconnaissance in the Yukon-Kuskokwim delta region, Alaska: U.S. Geological Survey Miscellaneous Geologic 1nvestigations Map $\{-223$, scale 1:500,000, 1 sheel.

Hoare, J.M., 1961, Geology and tectonic setring of lower Kuskokwim-Brislol Bay region. Alaska: American Association of Petroleum Geologists Bulletin, v. 45, p. $594-611$.

Hoare, J.M., and Condon, W.H., 1966. Geologic map of the Kwiguk and Black Quadrangles, western Alaska: U.S. Geological Survey Miscellaneous Geologic Investigations Map 1-469, scale 1:250.000, 1 sheet, with accompanying texi ( 7 p.).

1971. Geologic map of the Marshall Quadrangle, western Alaska: U.S. Geological Survey Miscellaneous Geologic Investigations Map I-668, scale 1:250,000, I sheet, with accompanying text (6 p.).

Hoare, J.M., and Coonrad, W.L., 1959a, Geology of the Bethel Quadrangle, Alaska: U.S. Geological Survey Miscellaneous Geologic Investigations Map I-285، scale $1: 250,000,1$ sheet.

1959b, Geology of the Russian Mission Quadrangle, Alaska: U.S. Geological Survey Miscellaneous Geologic Investigations Map I-292, scale 1:250,000, I sheet.
Hoare, J.M., and Coonrad, W.L., 1961, Geologic map of the Goodnews Quadrangle, Alaska: U.S. Geological Survey Miscellaneous Geologic Investigations Map I-339, scale $1: 63,360$, I sheet.

Krynine, P.D., 1948, The megascopic study and field classification of sedimentary rocks: Journal of Geology, $v$. 56, p. 130-165.

Palton,W.W., Jr., 1973, Reconnaissance geology of the northern Yukon-Koyukuk province, Alaska: U.S. Geological Survey Professional Paper 774-A, $17 \mathrm{p}$.

Pallon, W.W., Jr., and Miller, T.P., 1968, Regional geologic map of the Selawik and southeastern Baird Mountains Quadrangles, Alaska: U.S, Geological Survey Miscellaneous Geologic fnvestigations Map [-530, scale $1: 250,000,1$ sheet.

Sainsbury, C.L., Coleman, R.G., and Kachadoorian, R., 1970, Blueschist and related greenschist facies rocks of the Seward Peninsula, Alaska: U.S. Geological Survey Professional Paper $700 \mathrm{~B}$, p. B33-B42.

Smith, P.S., and Eakin, H.M., 1911, A geologic reconnaissance in southeastern Seward Peninsula and the Norton Bay-Nulato region: U.S. Geological Survey Bufletin 449,146 p.

Walker, R.G., 1978, Deep-water sandstone facies and ancient submarine fans: models for exploration for stratigraphic traps: American Association of Petroleum Geologists Bulletin, v. 62, p. 932-966. 
Table 1. Sample numbers cross-referenced to quadrangle maps, township, range, and stratigraphic unit.

[Letters designate sample collector: GB, Bolm; TF, Flett; WM, Lyle; JM, Mozehouse; IP, Palmer.]

\begin{tabular}{|c|c|c|c|c|c|c|}
\hline Locality & $\begin{array}{l}\text { Quadrangle map, } \\
\text { Alaska series, } \\
\text { (scale 1:250,000) }\end{array}$ & Sec. & T. & $\mathrm{R}$, & Sample & $\begin{array}{l}\text { Stratigraphic } \\
\text { unit }\end{array}$ \\
\hline 1 & Selawik & 22 & $9 \mathrm{~N}$ & $6 \mathrm{~W}$ & $39 \cdot \mathrm{GB} \cdot 78$ & Undifferentiated Tertiary \\
\hline 2 & Norton Bay & 25 & $9 S$ & $11 W$ & 43 to $45-G B-78$ & Shaktolik Group \\
\hline 3 & "1 & 12 & $16 S$ & $12 W$ & 54 to $57-68-78$ & " \\
\hline 4 & $"$ & 12 & $17 \mathrm{~S}$ & $12 \mathrm{~W}$ & 53 -GB-78 & ", \\
\hline 5 & Unalakleet & 1 & $19 \mathrm{~S}$ & $11 \mathrm{~W}$ & 9 to $10-$ GB- 78 & $"$ \\
\hline 6 & " & 4. & 19s, & low & 13 to $14 \cdot \mathrm{GB}-78$ & $"$ \\
\hline 7 & " & 36 & 185 & $10 \mathrm{~W}$ & 11 to $12 \cdot \mathrm{GB}-78$ & " \\
\hline 8 & " & 8 & $18 S$ & $8 \mathrm{~W}$ & 7 to 8 -GB-78 & $"$ \\
\hline 9 & ") & 28 & $20 \mathrm{~S}$ & $11 \mathrm{~W}$ & 32 to $35 \cdot G B-78$ & Undifferentiated Tertiary \\
\hline 10 & $"$ & 33, & 208 & $11 \mathrm{~W}$ & 29 to $30-\mathrm{GB}-78$ & Shaktolik Group \\
\hline 11 & $"$ & 13, & $21 \mathrm{~S}$ & $12 \mathrm{~W}$ & 24 to $28-G$ B. 78 & $"$ \\
\hline 12 & St, Michael & 34 & $26 S$, & $22 \mathrm{~W}$ & 22 to $23-G B-78$ & $"$ \\
\hline 13 & " & 32, & $27 \mathrm{~S}$ & $19 W$ & 2 to $3 \cdot G B \cdot 78$ & " \\
\hline \multirow[t]{2}{*}{14} & Marshall & 30 & $22 \mathrm{~N}$ & $83 \mathrm{~W}$ & $\begin{array}{l}17 \text { to } 20 \cdot 1 \mathrm{P}-78 \\
24-\mathrm{TF} \cdot 78\end{array}$ & Undifferentiated Cretaceous \\
\hline & & & & & 28 to $29 \cdot \mathrm{TF} \cdot 78$ & \\
\hline 15 & Kwiguk & 21 & $23 \mathrm{~N}$ & $77 \mathrm{~W}$ & 50 to $52-\mathrm{GB}-78$ & Shaktolik Group \\
\hline 16 & $"$ & 25 & $23 \mathrm{~N}$, & $77 \mathrm{~W}$ & $49-G B \cdot 78$ & " \\
\hline 17 & $"$ & 29 & $23 \mathrm{~N}$ & $76 \mathrm{~W}$ & 47 to $48-G B-78$ & ". \\
\hline 18 & Russian Mission & 11 & $18 N$ & $69 \mathrm{~W}$ & 1 to $16-1 P-78$ & Gemuk Group \\
\hline \multirow{2}{*}{19} & " & 25 & $18 \mathrm{~N}$, & $69 \mathrm{~W}$ & 39 to 44 JM- 78 & "' \\
\hline & & 30 & $18 \mathrm{~N}$, & $68 \mathrm{~W}$ & 71 to $87-W L-78$ & " \\
\hline 20 & Nunivak Island & 28 & $7 \mathrm{~N}$ & $89 w$ & I to $23-W L-78$ & Undifferentiated Cretaceous \\
\hline 21 & " & 31, & $7 \mathrm{~N}$, & $89 \mathrm{~W}$ & 24 10 37-WL-78 & " \\
\hline 22 & $"$ & 13 & $3 N$, & $100 \mathrm{~W}$ & 33 to $62 \cdot 1 \mathrm{P} \cdot 78$ & $"$ \\
\hline 23 & $"$ & 2 & IN, & $103 W$ & 66 to $68-1 P-78$ & "' \\
\hline 24 & $"$ & 5 & $1 \mathrm{~N}$ & $102 W$ & 63 to $65 \cdot I P \cdot 78$ & "s \\
\hline \multirow[t]{2}{*}{25} & Hethel & $31-32$ & 1s, & $67 W$ & $\begin{array}{l}1 \text { to } 38-J M \cdot 78 \\
45 \text { to } 49 \cdot 5 M \cdot 78\end{array}$ & Kuskokwim Group \\
\hline & & $34-36$ & 1S, & $68 \mathrm{~W}$ & $\begin{array}{l}2 \text { to } 19 \cdot \mathrm{TF}-78 \\
38 \text { to } 70 \cdot \mathrm{WL}-78\end{array}$ & "" \\
\hline 26 & " & 5 & is, & $64 W$ & 20 to $26-\mathrm{TF} \cdot 78$ & $"$ \\
\hline 27 & Goodnews Bay & 28 & $3 S_{1}$ & $63 W$ & 31 to $32 \cdot[\mathrm{P} \cdot 78$ & Gemuk Group \\
\hline 28 & " & 12, & $4 S_{1}$ & $64 \mathrm{~W}$ & 21 to $30 \cdot 1 P \cdot 78$ & " \\
\hline
\end{tabular}


Table 2. Summary of organic carbon content and visual kerogen data.

[Determinations by Geochem Laboratories, Inc., Houston, Texas. Two numbers in "organic carbon" column indicate sample was run twice to test repeatability of analysis. TAI: scale from 1 (unaltered) to 4 (severely altered); underlined number indicates dominant rank of alteration. Kerogens listed in order of decreasing abundance: predominant $(60$ $100 \%)$; secondary (20.40\%); trace (1-20\%). Al, algal; Am, amorphous-sapropel; $\mathrm{C}, \mathrm{coal} ; \mathrm{H}$, herbaceous-spore/cuticle; $H^{*}$, degraded herbaceous; $W$, woody; $U$, unidentified malerial. A hyphen between kerogen types indicates subequal abundance. Kerogen types enclosed in parentheses following Am are recognizable degraded constituents of the amorphous population. Minor constituents of the trace population are indicaled in parentheses following the code for the more abundant trace kerogen types. I

\begin{tabular}{|c|c|c|c|c|}
\hline \multirow[b]{2}{*}{ Locality } & \multirow[b]{2}{*}{ Sample } & \multirow{2}{*}{$\begin{array}{c}\text { Organic } \\
\text { carbon } \\
(\%)\end{array}$} & \multicolumn{2}{|c|}{ Visual kerogen data } \\
\hline & & & Type & $\begin{array}{l}\text { Thermal alter } \\
\text { index (TAI) }\end{array}$ \\
\hline \multicolumn{5}{|c|}{ Gemuk Group } \\
\hline 18 & $\begin{array}{l}1-1 \mathrm{P}-78 \\
1-\mathrm{IP}-78 \\
6 \cdot-1 \mathrm{P}-78 \\
8-\mathrm{IP}-78 \\
10 \cdot \mathrm{IP}-78 \\
16 \cdot \mathrm{IP}-78\end{array}$ & $\begin{array}{l}0.08 \\
0.05 \\
0.08 \\
0.10 \\
0.05 \\
0.08\end{array}$ & $\begin{array}{l}\mathrm{H} ; \because \\
W ;-\mathrm{H} \\
\operatorname{Am}\langle A|) ; \cdot ; \mathrm{H} \\
\operatorname{Am}(\mathrm{Al}) \cdot \mathrm{H} ; \cdot ; \cdot \\
\mathrm{H} ; A \mathrm{Am}-\mathrm{W} ; \\
\mathrm{H} ; \operatorname{Am}(\mathrm{Al})\end{array}$ & $\begin{array}{l}1+\text { to } 2- \\
2-\text { to } 2 \\
1+ \\
2- \\
2-\text { to } 2 \\
1+\end{array}$ \\
\hline 19 & $\begin{array}{l}41 \text {-JM-78 } \\
44 \text {-JM-78 } \\
71 \text {-WL-78 } \\
76 \text {-WL-78 } \\
80-W L-78 \\
82-W L-78 \\
86 \text {-WL-78 }\end{array}$ & $\begin{array}{c}0.07 \\
0.59 \\
0.22 \\
0.08 \\
0.08 \\
0.18 \\
0.14 ; 0.24\end{array}$ & $\begin{array}{l}\mathrm{H} \cdot W ; C ;- \\
W-C ; H ; \cdot \\
H ; W ;- \\
H-W ;-; \\
W ; H ; C \\
H-W ;-C C \\
H ; W ;-\end{array}$ & $\begin{array}{l}2 \text { to } 2+ \\
2 \text { to } 2+ \\
2 \\
2-\text { to } 2 \\
2 \text { to } 2+ \\
2 \\
2-\text { to } 2\end{array}$ \\
\hline 27 & $32 \cdot \mathrm{IP} \cdot 78$ & 0.14 & $W ; H_{;-}$ & 2 to $2+$ \\
\hline 28 & $\begin{array}{l}22 \cdot I \mathrm{IP} \cdot 78 \\
25 \cdot 1 \mathrm{P}-78\end{array}$ & $\begin{array}{l}0.06 \\
0.07\end{array}$ & $\begin{array}{l}\mathrm{H} ;-; \mathrm{W} \cdot \mathrm{C} \\
\mathrm{H} ; \mathrm{W} ; \mathrm{C}\end{array}$ & $\begin{array}{l}3 \text { to } 3+ \\
3 \text { to } 3^{+}\end{array}$ \\
\hline \multicolumn{5}{|c|}{ Shaktolik Group } \\
\hline 2 & $44-G B-78$ & 0.41 & $H-W ;: ; C$ & $2-102$ \\
\hline 3 & $56-\mathrm{GB}-78$ & 4.30 & $\mathrm{~W} \cdot \mathrm{C}: \mathrm{H}:$ & $3+$ \\
\hline 5 & $10-G B-78$ & 0.18 & $\mathrm{~W}-\mathrm{C}_{i} \mathrm{H} ;$ & $3-$ to 3 \\
\hline 6 & $14 \cdot \mathrm{GB} \cdot 78$ & 0.21 & $\mathrm{H} ; \mathrm{W}-\mathrm{C} ;-$ & $3 \cdot$ to 3 \\
\hline 7 & $12 \cdot G B \cdot 78$ & 0.61 & $\mathrm{H} \cdot \mathrm{W}-\mathrm{C}_{i} \cdot ;-$ & 2 to $2^{+}$ \\
\hline 8 & $8 \cdot G B-78$ & 0.18 & $\mathrm{~W}-\mathrm{C}_{i} \mathrm{H}_{i} \cdot$ & $3 \cdot$ to 3 \\
\hline 10 & $30-G B-78$ & 0.38 & $\mathrm{~W}-\mathrm{C} ; \mathrm{H} ;-$ & $3-$ to 3 \\
\hline 11 & $25 \cdot \mathrm{GB} \cdot 78$ & 0.37 & $\mathrm{H} \cdot \mathrm{W} \cdot \mathrm{C}: ;-$ & 3. to 3 \\
\hline 12 & $23-\mathrm{GB} \cdot 78$ & 0.10 & $\mathrm{~W} \cdot \mathrm{C} ; \mathrm{H} ; \cdot$ & $2102+$ \\
\hline 13 & $3-G B-78$ & 0.45 & $\mathrm{~W}-\mathrm{C}_{;} ; \mathrm{H}$ & 3 to $3+$ \\
\hline 15 & $50-G B-78$ & 0.17 & $\mathrm{~W}-\mathrm{C} ;-; \mathrm{H}$ & $2+$ to $3-$ \\
\hline 17 & 48-GB-78 & $0.89 ; 0.82$ & W-C; $\mathrm{H}_{i-}$ & 2 to $2+$ \\
\hline
\end{tabular}


Table 2. (cont.)

\begin{tabular}{|c|c|c|c|c|}
\hline \multirow[b]{2}{*}{ Locality } & \multirow[b]{2}{*}{ Sample } & \multirow{2}{*}{$\begin{array}{c}\text { Organic } \\
\text { carbon } \\
\langle \%\rangle\end{array}$} & \multicolumn{2}{|c|}{ Visual kerogen data } \\
\hline & & & Type & $\begin{array}{c}\text { Thermal alteratio } \\
\text { index (TAI) }\end{array}$ \\
\hline \multicolumn{5}{|c|}{ Kuskokwim Group } \\
\hline 25 & $\begin{array}{l}\text { 4-JM-78 } \\
6 \text {-JM-78 } \\
\text { 10-JM-78 } \\
15-J M-78 \\
25-J M-78 \\
\text { 35-JM-78 } \\
\text { 47.JM-78 } \\
\text { 8-TF-78 } \\
12-T F-78 \\
\text { 17-TF-78 } \\
\text { 38-WL-78 } \\
\text { 42-WL-78 } \\
\text { 46-WL-78 } \\
\text { 52-WL-78 } \\
\text { 55-WL-78 } \\
\text { 60-WL-78 } \\
\text { 64-WL-78 }\end{array}$ & $\begin{array}{c}0.48 \\
0.56 \\
1.02 \\
0.29 \\
0.25 ; 0.30 \\
0.49 \\
0.48 \\
0.40 \\
0.56 \\
0.60 \\
0.92 \\
0.70 \\
0.51 \\
1.05 \\
0.65 ; 0.63 \\
0.26 \\
0.58\end{array}$ & 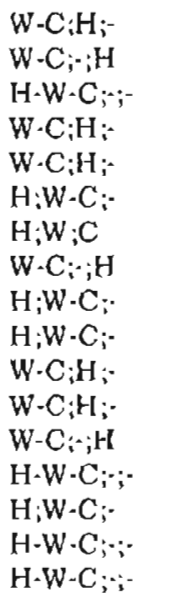 & $\begin{array}{l}2+\text { to } 3- \\
2 \text { to } 2+ \\
2 \text { to } 2+ \\
2 \text { to } 2+ \\
2 \text { to } 2+ \\
2 \text { to } 2+ \\
2 \text { to } 2+ \\
2+\text { to } 3- \\
2 \text { to } 2+ \\
2-\text { to } 2 \\
2 \text { to } 2+ \\
2 \text { to } 2+ \\
2 \text { to } 2+ \\
2 \text { to } 2+ \\
2 \\
2 \text { to } 2+ \\
2 \text { to } 2+\end{array}$ \\
\hline 26 & $\begin{array}{l}20-T F-78 \\
24-T F-78\end{array}$ & $\begin{array}{l}0.52 \\
0.16\end{array}$ & $\begin{array}{l}W-C_{;-; H} \\
W-C_{;} ; H\end{array}$ & $\begin{array}{l}2 \text { to } 2+ \\
3+\end{array}$ \\
\hline \multicolumn{5}{|c|}{ Undifferentiated Cretaceous } \\
\hline 14 & $\begin{array}{l}20-1 P-78 \\
29-1 P-78\end{array}$ & $\begin{array}{l}0.10 \\
0.29\end{array}$ & $\begin{array}{l}\mathrm{H} ;-; \mathrm{C} \\
\mathrm{H} ; \mathrm{W} \cdot \mathrm{C} ;-\end{array}$ & $\begin{array}{l}4-\text { to } 4 \\
4 \cdot \text { to } 4\end{array}$ \\
\hline 20 & $\begin{array}{l}3 \cdot W L-78 \\
7 \cdot W L-78 \\
9 \cdot W L-78 \\
13 \cdot W L-78 \\
16-W L-78 \\
19-W L-78 \\
21 \cdot W L-78\end{array}$ & $\begin{array}{l}0.11 \\
0.08 \\
0.07 \\
0.15 \\
0.38 \\
0.10 \\
0.09\end{array}$ & $\begin{array}{l}\mathrm{W} ; \mathrm{H} ;- \\
\mathrm{W} ; ; \mathrm{H} \cdot \mathrm{C} \\
\mathrm{W} \cdot \mathrm{C} ; \mathrm{H} ;- \\
\mathrm{W} ;-; \mathrm{H}-\mathrm{C} \\
\mathrm{H}-\mathrm{W} ;-\mathrm{C} \\
\mathrm{W} \cdot \mathrm{C} ; \mathrm{I}-\mathrm{I}_{;} \\
\mathrm{W} \cdot \mathrm{C} ; \mathrm{H} ;-\end{array}$ & $\begin{array}{l}2 \text { to } 2+ \\
2 \text { to } 2+ \\
2+\text { to } 3 \\
2 \\
2 \text { to } 2+ \\
2 \text { to } 2+ \\
2+\end{array}$ \\
\hline 21 & $\begin{array}{l}24-W L-78 \\
27-W L-78 \\
31-W L-78\end{array}$ & $\begin{array}{c}0.19 \\
0.08 \\
0.12: 0.18\end{array}$ & $\begin{array}{l}\mathrm{H}-\mathrm{W}-\mathrm{C} ;-;- \\
\mathrm{W}-\mathrm{C} ;-; \mathrm{H} \\
\mathrm{W} ; \mathrm{H} ; \mathrm{Am}-\mathrm{C}\end{array}$ & $\begin{array}{l}2 \text { to } 2+ \\
2 \text { to } 2+ \\
2 \text { to } 2+\end{array}$ \\
\hline 22 & $\begin{array}{l}33-I P-78 \\
36-I P-78 \\
39-I P-78 \\
44-I P-78 \\
49-I P-78 \\
53-I P-78 \\
56-I P-78 \\
59-I P-78\end{array}$ & $\begin{array}{c}0.27 \\
0.12 \\
0.28 \\
0.18 \\
0.19 \\
0.28,0.28 \\
0.15 \\
0.18\end{array}$ & $\begin{array}{l}\mathrm{W}-\mathrm{C} ; \mathrm{H} ;- \\
\mathrm{W}-\mathrm{C} ; \mathrm{H} ;- \\
\mathrm{W}-\mathrm{C} ;-; \mathrm{H} \\
\mathrm{W}-\mathrm{C} ;-; \mathrm{H} \\
\mathrm{W}-\mathrm{C} ;-; \mathrm{H} \\
\mathrm{W}-\mathrm{C} ; \mathrm{H} ; \\
\mathrm{W}-\mathrm{C} ;-; \mathrm{H} \\
\mathrm{W}-\mathrm{C} ;-; \mathrm{H}\end{array}$ & $\begin{array}{l}3-\text { to } 3 \\
2+\text { to } 3- \\
3-\text { to } 3 \\
3-\text { to } 3 \\
3-\text { to } 3 \\
3-\text { to } 3 \\
2+\text { to } 3 . \\
3+\text { to } 4 .\end{array}$ \\
\hline 23 & $66-1 \mathrm{P}-78$ & 0.54 & $\mathrm{~W}-\mathrm{C} \cdot \mathrm{H}_{;}-$ & $4 \cdot$ to 4 \\
\hline 24 & $63-I P \cdot 78$ & 0.87 & $\mathrm{~W} \cdot \mathrm{C}_{i} ; \mathrm{H}$ & $3+$ to $4-$ \\
\hline
\end{tabular}


Table 3. Geochemical analyses of $C_{15}+$ extracled material in rock.

[Determinations by Geochem Laboratories, Inc., Houston, Texas. All values in parts per million. NSO's are nitrogensulfur-oxygen derivatives. Fifty-eight samples were not subjected to complete analysis due to the small amount ( 0.01 $\mathrm{gm}$ ) of $\mathrm{nC}_{5}$ soluble in the $\mathrm{C}_{15}+$ total solvent extractable bitumen.1

\begin{tabular}{|c|c|c|c|c|c|c|c|c|c|c|}
\hline \multirow[b]{2}{*}{ Locality } & \multirow[b]{2}{*}{ Sample } & \multirow{2}{*}{$\begin{array}{l}\text { Total } \\
\text { extract } \\
(\mathrm{H}+\mathrm{N})\end{array}$} & \multicolumn{3}{|c|}{ Hydrocarbons $(\mathrm{H})$} & \multicolumn{4}{|c|}{ Nonhy drocarbons $(\mathrm{N})$} & \multirow[b]{2}{*}{ Total } \\
\hline & & & $\begin{array}{l}\text { Parafifin- } \\
\text { naphthene }\end{array}$ & $\begin{array}{l}\text { Aro- } \\
\text { malic }\end{array}$ & Total & $\underline{\text { Sulfur }}$ & $\begin{array}{c}\text { Precip. } \\
\text { asphaltene }\end{array}$ & $\begin{array}{l}\text { Eluted } \\
\text { NSO's } \\
\end{array}$ & $\begin{array}{l}\text { Noneluted } \\
\text { NSO's }\end{array}$ & \\
\hline \multicolumn{11}{|c|}{ Gemuk Group } \\
\hline 18 & $1-I P-78$ & 117 & $\cdots$ & $\cdots$ & $\cdots$ & $\cdots$ & 94 & $\cdots$ & $\therefore$ & $-\cdot$ \\
\hline & $4 \cdot \mathrm{IP}-78$ & 170 & $\cdots$ & $\cdots$ & $\cdots$ & $\cdots$ & 135 & $\cdots$ & $\cdots$ & -- \\
\hline & $6-\mathrm{IP} \cdot 78$ & 150 & $\cdots$ & $\cdots$ & $\cdots$ & $\cdots$ & 118 & $\cdots$ & $\cdots$ & $\cdots$ \\
\hline & 8-LP-78 & 155 & $\cdots$ & . & $\cdots$ & $\cdots$ & 115 & $\cdots$ & $\ldots$ & $\cdots$ \\
\hline & $10-[\mathrm{P} \cdot 78$ & 96 & $\cdots$ & $\cdots$ & $\cdots$ & $\ldots$ & 50 & $\ldots$ & - . & $\ldots$ \\
\hline & $16-I P \cdot 78$ & 168 & $\cdots$ & $\cdots$ & $\cdots$ & $\cdots$ & 122 & - & -- & - \\
\hline 19 & $41 \mathrm{JM} \cdot 78$ & 109 & $\cdots$ & $\cdots$ & $\cdots$ & $\cdots$ & 73 & $\cdots$ & $\cdots$ & $\cdots$ \\
\hline & 44 ปM-78 & 110 & $\cdots$ & $\cdots$ & $\ldots$ & $\ldots$ & 73 & 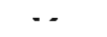 & $\cdots$ & $\cdots$ \\
\hline & 71-WL-78 & 128 & - & $\cdots$ & $\cdots$ & $\cdots$ & 72 & $\cdots$ & $\cdots$ & $\cdots$ \\
\hline & 76-WL-78 & 194 & $\ldots$ & $\cdots$ & $\cdots$ & $\cdots$ & 124 & $\cdots$ & $\cdots$ & $\cdots$ \\
\hline & $80 \cdot W \zeta-78$ & 144 & $\cdots$ & $\cdots$ & $\cdots$ & $\cdots$ & 115 & $\cdots$ & $\cdots$ & $\cdots$ \\
\hline & 82-WL-78 & 292 & 46 & 26 & 72 & $\cdots$ & 163 & 50 & 7 & 220 \\
\hline & $86-W L-78$ & 115 & $\cdots$ & $-\cdot$ & $\cdots$ & $\cdots$ & 84 & $\cdots$ & $\cdots$ & $\cdots$ \\
\hline 27 & $32-I P-78$ & 125 & $\cdots$ & - & $\cdots$ & $\cdots$ & 78 & $\cdots$ & $\cdots$ & - \\
\hline 28 & $22-1 P-78$ & 134 & $\cdots$ & $\cdots$ & $\cdots$ & $\cdots$ & 90 & $\cdots$ & $\cdots$ & $\cdots$ \\
\hline & $25-[\mathrm{P}-78$ & 271 & 18 & 6 & 23 & 72 & 138 & 26 & 12 & 248 \\
\hline \multicolumn{11}{|c|}{ Shaktolik Group } \\
\hline 2 & $44-G B-78$ & 618 & 21 & 77 & 98 & $\cdots$ & 374 & 111 & 35 & 520 \\
\hline 3 & $56 \cdot G B-78$ & 211 & $\cdots$ & $\cdots$ & $\cdots$ & $\cdots$ & 162 & $\cdots$ & $\cdots$ & $\cdots$ \\
\hline 5 & $10-G B-78$ & 121 & $\cdots$ & $\cdots$ & $\cdots$ & $\cdots$ & 112 & $\cdots$ & $\cdots$ & $\cdots$ \\
\hline 6 & $14-\mathrm{GB} \cdot 78$ & 94 & $\cdots$ & $\cdots$ & $\cdots$ & $\cdots$ & 70 &.- & $\cdots$ & $\cdots$ \\
\hline 7 & $12 \cdot G B-78$ & 127 & $\cdots$ & $\cdots$ & $\cdots$ & $\cdots$ & 86 & $\cdots$ & $\cdots$ & $\cdots$ \\
\hline 8 & $8-G B \cdot 78$ & 86 & $\cdots$ & $\cdots$ & $\cdots$ & $\cdots$ & 61 & $\cdots$ & $\cdots$ & $\cdots$ \\
\hline 10 & $30 \cdot G B-78$ & 98 & $\ldots$ & $\cdots$ & $\cdots$ & $\cdots$ & 75 & $\cdots$ & $\cdots$ & $\cdots$ \\
\hline 11 & 25-GB-78 & 140 & $\cdots$ & $\cdots$ & $\cdots$ & $\cdots$ & 96 & $\cdots$ & $\cdots$ & $\cdots$ \\
\hline 12 & $23-G B-78$ & 81 & $\cdots$ & $\cdots$ & $\cdots$ & $\cdots$ & 73 & $\cdots$ & $\cdots$ & $\cdots$ \\
\hline 13 & $3-G B-78$ & 140 & $-\cdot$ & $\cdots$ & $\cdots$ & $\cdots$ & 97 & $\cdots$ & $\cdots$ & $\cdots$ \\
\hline 16 & $50-G B-78$ & 62 & $\cdots$ & $\cdots$ & $\cdots$ & $\cdots$ & 56 &. & $\cdots$ & - \\
\hline 17 & $48 \cdot G B \cdot 78$ & 183 & $\cdots$ & $\cdots$ & $\cdots$ & $\cdots$ & 130 & $\cdots$ & - & $\cdots$ \\
\hline
\end{tabular}


Table 3. (cont.)

\begin{tabular}{|c|c|c|c|c|c|c|c|c|c|c|}
\hline \multirow[b]{2}{*}{ Locality } & \multirow[b]{2}{*}{ Sample } & \multirow{2}{*}{$\begin{array}{c}\text { Total } \\
\text { extract } \\
(\mathrm{H}+\mathrm{N}) \\
\end{array}$} & \multicolumn{3}{|c|}{ Hydrocarbons $(\mathrm{H})$} & \multicolumn{5}{|c|}{ Nonkydracarbons $(\mathrm{N})$} \\
\hline & & & $\begin{array}{l}\text { Paraffin- } \\
\text { naphthene }\end{array}$ & $\begin{array}{l}\text { Aro- } \\
\text { matic }\end{array}$ & Total & $\underline{\text { Sulfur }}$ & $\begin{array}{c}\text { Precip. } \\
\text { asphaltene }\end{array}$ & $\begin{array}{l}\text { Eluted } \\
\text { NSO's }\end{array}$ & $\begin{array}{c}\text { Noneluted } \\
\text { NSO's } \\
\end{array}$ & Total \\
\hline \multicolumn{11}{|c|}{ Kuskokwim Group } \\
\hline \multirow[t]{17}{*}{25} & $4-J M \cdot 78$ & 100 & $\ldots$ & . & . & . & 79 & - & $\cdots$ & $\cdots$ \\
\hline & 6-JM-78 & 281 & - & $\cdots$ & $\cdots$ & $\therefore$ & 183 & . & - & $\cdots$ \\
\hline & 10-JM-78 & 181 & $\cdots$ & $\cdots$ & $\cdots$ & $\cdots$ & 107 & $\cdots$ & . & $\cdots$ \\
\hline & $15-\sqrt{M}-78$ & 170 & $\cdots$ & $\cdots$ & - & $\cdots$ & 96 & $\cdots$ & $\cdots$ & . \\
\hline & $25 \cdot \mathrm{JM} \cdot 78$ & 220 & .. & . & . & . & 164 & $\cdots$ & $\cdots$ & $\cdots$ \\
\hline & $35-\sqrt{M}-78$ & 229 & . & . & . & $\ldots$ & 145 & - & $\cdots$ & $\cdots$ \\
\hline & 47-JM-78 & 205 & $\cdots$ & $\cdots$ & $\cdots$ & $\cdots$ & 107 & $\ldots$ & - & - \\
\hline & 8-TF-78 & 280 & $\cdots$ & $\cdots$ & $\cdots$ & $\cdots$ & 212 & . & $\ldots$ & $\cdot-$ \\
\hline & 12-TF-78 & 338 & 9 & 51 & 60 & $\cdots$ & 224 & 49 & 6 & 278 \\
\hline & $17 \cdot T^{\top} F \cdot 78$ & $\$ 11$ & 8 & 56 & 64 & -. & 280 & 57 & 10 & 347 \\
\hline & $38-W L-78$ & 226 & $\ldots$ & . & $\ldots$ & $\ldots$ & 147 & - & - - & $\cdots$ \\
\hline & 42-WL-78 & 276 & 9 & 53 & 62 & $\cdots$ & 164 & 48 & 8 & 215 \\
\hline & 46.WL-78 & 198 & $\cdots$ & $\cdots$ & $\cdots$ & $\cdots$ & 142 & $\cdots$ & $\ldots$ & $\cdots$ \\
\hline & $52 \cdot W L-78$ & 933 & 7 & 11 & 18 & $\therefore$ & 723 & 93 & 100 & 915 \\
\hline & $55-W L-78$ & 370 & 5 & 65 & 70 & $\cdots$ & 199 & 92 & 9 & 300 \\
\hline & $60-W L-78$ & 359 & 8 & 63 & 71 & $\cdots$ & 203 & 72 & 13 & 288 \\
\hline & $64-W L \cdot 78$ & 292 & 10 & 46 & 56 & $\cdots$ & 172 & 51 & 13 & 236 \\
\hline \multirow[t]{2}{*}{26} & 20-TF-78 & 124 & -- & - & $\cdots$ & $\cdots$ & 88 & $\cdots$ & $\ldots$ & $\ldots$ \\
\hline & $24-\mathrm{TF}-78$ & 91 & $\cdots$ & $\ldots$ & $\cdots$ & $\ldots$ & 51 & . & $\cdots$ & . \\
\hline
\end{tabular}

\begin{tabular}{|c|c|c|c|c|c|c|c|c|c|c|}
\hline \multirow[t]{2}{*}{14} & 20-IP-78 & 126 & - & - - & $\cdots$ & $\cdots$ & 75 & . & . & $\cdots$ \\
\hline & 29-TF-78 & 316 & $\cdots$ & - & - & $\ldots$ & 260 & -- & $\therefore$ & $\cdots$ \\
\hline \multirow[t]{7}{*}{20} & $3-W L-78$ & 119 & $\cdots$ & $\cdots$ & - & $\cdots$ & 90 & $\cdots$ & $\cdots$ & $\cdots$ \\
\hline & $7 . W L-78$ & 199 & $\ldots$ & $\ldots$ & $\ldots$ & $\ldots$ & 125 & .. & $\cdots$ & $\ldots$ \\
\hline & 9.WL. 78 & 88 & $\ldots$ & $\ldots$ & $\ldots$ & $\cdots$ & 55 & $\ldots$ & $\ldots$ & . \\
\hline & 13.WL-78 & 79 & $\ldots$ & - - & $\cdots$ & $\ldots$ & 48 & $\ldots$ & $\ldots$ & $\cdots$ \\
\hline & 16 -WL- 78 & 242 & $\ldots$ & $\ldots$ & $\cdots$ & $\ldots$ & 144 & $\ldots$ & - & .- \\
\hline & $19-W L-78$ & 153 & $\cdots$ & - & $\cdots$ & $\cdots$ & 117 & $\ldots$ & $\cdots$ & - \\
\hline & 21-WL-78 & 104 & . & $\cdots$ & $\cdots$ & $\ldots$ & 63 & $\ldots$ & $\ldots$ & - - \\
\hline \multirow[t]{3}{*}{21} & $24-W L-78$ & 294 & 11 & 34 & 45 & $\cdots$ & 132 & 83 & 34 & 249 \\
\hline & $27-W L \cdot 78$ & 235 & $\cdots$ & . & $\ldots$ & $\ldots$ & 165 & . & $\ldots$ & - \\
\hline & $31-W L-78$ & 824 & $\because$ & $\ldots$ & $\cdots$ & $\cdots$ & 773 & $\ldots$ & $\cdots$ & $\cdots$ \\
\hline \multirow[t]{8}{*}{22} & $33-L P-78$ & 117 & $\cdots$ & $\cdots$ & $\ldots$ & - & 69 & . & . & . \\
\hline & 36-IP-78 & 109 & $\ldots$ & - . & $\cdots$ & $\cdots$ & 74 & . & $\ldots$ & $\cdots$ \\
\hline & $39-I P-78$ & 185 & $\cdots$ & $\cdots$ & $\ldots$ & $\cdots$ & 92 & $\cdots$ & . & .. \\
\hline & $44-I P-78$ & 194 & $\cdots$ & $\cdots$ & - . & $\cdots$ & 106 & $\ldots$ & $\ldots$ & . \\
\hline & 49.IP-78 & 116 & - & $\cdots$ & $\cdots$ & $\ldots$ & 59 & $\therefore$ & $\cdots$ & $\cdots$ \\
\hline & 53-IP-78 & 161 & $\cdots$ & $\cdots$ & $\cdots$ & $\cdots$ & 112 & $\cdots$ & $\cdots$ & $\cdots$ \\
\hline & $56-I P-78$ & 142 & $\cdots$ & $\cdots$ & $\cdots$ & $\cdots$ & 84 & $\cdots$ & $\cdots$ & $\cdots$ \\
\hline & $59 \cdot[P \cdot 78$ & 195 & $\cdots$ & $\cdots$ & - & $\cdots$ & 161 & $\cdots$ & - & $\cdots$ \\
\hline 23 & $66-1 P-78$ & 222 & $\cdots$ & $\cdots$ & $\cdots$ & $\cdots$ & 181 & $-\cdot$ & $\cdots$ & $\cdots$ \\
\hline 24 & $63-\mathrm{IP}-78$ & 100 & $\cdots$ & . & . & - & 76 & $\cdots$ & $\ldots$ & $\cdots$ \\
\hline
\end{tabular}


Table 4. Porosity and permeability.

[Determinations by Chemical \& Geological Laboratories of Alaska, Inc. "F" in the permeability column indicates sample is fractured.]

Locality

18

19

27

28

2

3

4

5

6

7

8

10

11

12

13

15

16

17
Sample

3-IP. 78

13-IP-78

14-IP-78

39- $\mathrm{NM}-78$

43-JM-78

75-WL-78

79.WL-78

84-WL-78

85-WL-7 8

$3 \lambda \cdot 1 P \cdot 78$

$21 \cdot[\mathrm{P} \cdot 78$

45-GB-78

54-GB-78

55-GB.78

53-GB-78

9-GB-78

13-GB-78

11-GB-78

7-GB-78

$29 \cdot G B \cdot 78$

27-GB-78

22-GB-78

2-GB-78

61-GB-78

52-GB.78

49-GB-78

47-GB-78
Errective

porosity

(\%)

Gemuk Group

\section{6}

4.7

6.7

7.5

1.0

0.2

4.3

5.5

3.9

1.9

2.1

Shaktolik Group

2.7

1,1

0.2

1.2

3.6

2.0

2.1

2.2

1.2

8.1

2.9

2.5

0.4

5.1

7.2

0.9
Horizontal

permeability (millidarcies)
0.40
0.31
0.30
2.07
0.03
0.01
0.07
$6.31(F)$
0.04
$48(\mathrm{~F})$
0.07

0.07

0.05

0.06

0.05

0.30

0.08

0.09

0.14

0.08

0.12

0.08

0.15

0.05

2.04

1.76

0.07 
Table 4. (cont.)

Effective

porosity

Locality

25

1-JM-78

$9 \sqrt{\mathrm{M}}-78$

14.JM-78

24.JM.78

$28 \cdot \mathrm{MM} \cdot 78$

$29 \cdot \mathrm{JM}-78$

34-JM-78

38-JM-78

45.JM-78

$49 \cdot 3 \mathrm{M} \cdot 78$

3-TF-78

$4-\mathrm{TF} \cdot 78$

5-TF-78

6-TF-78

7.TF-78

11 -TF- 78

15-TF-78

16-TF-78

41-WL-78

49-WL-78

$51-W L-78$

58-WL-78

59.WL.78

67.WL-78

68-WL-78

69-WL-78

70-WL-78

(\%)

\section{Kuskokwim Group}

1.3
45.WL-78

0.07

0.08

0.10

0.08

0.10

0.10

0.10

0.06

0.11

0.08

0.09

0.24

0.13

0.05

0.08

0.02

0.02

0.03

0.03

0.04

0.02

0.03

0.03

0.03

0.03

0.04

0.05

0.04

0.03

Undifferentiated Cretaceous

14

$$
\begin{aligned}
& \text { 17-IP-78 } \\
& 18 \cdot I P \cdot 78 \\
& 19 \cdot I P \cdot 78 \\
& 28-T F \cdot 78
\end{aligned}
$$

0.2

0.3

0.4

4.9

7.2

2.8

5.4

4.7

5.8

7.4

6.3

2.2

2.5

5.2

ธ. 6

42-IP-78

48-IP-78

$52 \cdot 1 \mathrm{P}-78$

62-IP-78

Undifferentiated Tertiary
0.05

0.06

0.05

0.01

0.21

0.02

0.50

0.06

0.13

0.04

0.08

0.06

0.05

0.06

0.13

1.49

48 
Table 5. Summary of micropoleonlological age and environment dala.

[Determinations by Anderson, Warren \& Associates, Inc., San Diego, California, Frequency symbols used: $R$, rare; $F$, frequent; $C$, common: $A$, abundant. I

\section{Gemuk Group}

Locality 18

2-JP-78: Radiolaria (silicified) (R). Orange-brown silty mudstone.
Age:
Indeterminate
Environment: Probable marine

5-IP-78: Barren. Orange phosphatic(?) shale.
Age:
Indeterminate
Environment: Indeterminate

7-IP-78: Barren. Orange-brown mudstone.

Age: Indeterminate

Environment: Indeterminate

9-IP-78: Barren. Orange-brown mudstone.
Age:
Indeterminate
Environment: Indeterminate

11-IP-78: Barren, Orange-brown mudstone.

Age: Indeterminate

Environment: Indeterminate

15-IP-78: Barren. Dark-bluish-green chert.
Age:
Indeterminate

Environment: Indeterminate

Locality 19

72-WL-78: Barren. Greenish-brown siliceous shale or chert.
Age:
Indeterminate
Environment: Indeterminate

77-WL-78: Cenosphaera? spp. (C). Dark-orange-brown siliceous mudstone.
Age:
Indeterminate
Environment: Possible open maxine

81-WL-78 Barren. Greenish-gray iron-stained siliceous shale.
Age:
Indeterminate
Environment: Indeterminate

83-WL-78: Cenosphaera? spp. (F), spicules (R). Multicolored siliceous shale or chert.
Age: Indeterminate
Environment: Possible open marine 
Table 5. (cont.)

Gemuk Group (cont.)

87-WL-78: Barren. Dark-orangish brown siliceous shale.

$\begin{array}{ll}\text { Age: } & \text { Indeterminate } \\ \text { Environment: Indeterminate }\end{array}$

Locality 28

23-IP-78: Barren. Black and brown siliceous shale or chert.
Age:
Indeterminate
Environment: Indeterminate

26.IP-78: Arenaceous sp. (R), Cenosphaera spp. (R). Dark-gray to black sandy chert.

$\begin{array}{ll}\text { Age: } & \text { Indeterminate } \\ \text { Environment: Probable marine }\end{array}$

Shaktolik Group

Locality 2

43-GB-78: Barren. Orange-tan angular fine-grained sandstone.
Age: Indeterminate
Environment: Indeterminale

Locality 3

57-GB-78: Eponides? sp. (R). Black schist(?)

$$
\begin{array}{ll}
\text { Age: } & \text { Indeterminate } \\
\text { Environment: Possible marine }
\end{array}
$$

\section{Locality 5}

10.GB-78: Barren. Dark-yellowish-gray mudstone.

$\begin{array}{ll}\text { Age: } & \text { Indelerminate } \\ \text { Environment: Indeterminate }\end{array}$

Locality 6

14-GB-78: Barren. Black and brown muddy fine-grained sandstone.
Age:
Indeterminate
Environment: Indelerminate

Locality 7

12-GB-78: Barren. Dark-gray micaceous shale,
Age:
Indeterminate
Environment: Indeterminate

Locality 8

8-GB-78: Barren. Fecal pellets (C). Dark-gray to black sandy shale.
Age:
Indeterminate
Environment: Indeterminale 
Table 5. (cont.)

Shaktolik Group (cont.)

Locality 10

30-GB-78: Barren. Fecal pellets (F). Dark-gray micaceous shale.

$$
\text { Age: Indeterminate }
$$

Environment: Indeterminale

Localiuy 11

28-GB-78: Echinoid remains ( $R$ ). Black sandy shale.

$$
\begin{array}{ll}
\text { Age: } & \text { Indeterminate } \\
\text { Environment: Possible marine }
\end{array}
$$

Locality 12

23-GB-78: Barren. Brownish-gray micaceous mudstone.

$$
\begin{array}{ll}
\text { Age: } & \text { Indeterminate } \\
\text { Environment: Indeterminate }
\end{array}
$$

$\underline{\text { Locality } 13}$

9.GB-78: Barren, Black shale.

$$
\begin{array}{ll}
\text { Age: } & \text { Indeterminate } \\
\text { Environment: Indeterminate }
\end{array}
$$

\section{Locality 15}

50-GB-78: Cibicides? sp. (R), Cenosphaera spp. (R). Black sandy shale.

$$
\begin{array}{ll}
\text { Age: } & \text { Indeterminate } \\
\text { Environment: Probable marine }
\end{array}
$$

\section{Locality 17}

48-G8-78: Baryen. Black shale.

$$
\begin{array}{ll}
\text { Age: } & \text { Indeterminate } \\
\text { Environment: } & \text { Indeterminate }
\end{array}
$$

\section{Kusk okwim Group}

\section{Locality 25}

Barren. Dark-brownish-gray micaceous mudstone.

$$
\begin{array}{ll}
\text { Age: } & \text { Indeterminate } \\
\text { Environmenl: Indeterminate }
\end{array}
$$

7-JM-78: Barren. Dark-brown ish-gray micaceous mudstone.

$$
\begin{array}{ll}
\text { Age: } & \text { Indeterminale } \\
\text { Environment: Indeterminale }
\end{array}
$$

11-JM-78: Barren. Shell fragments (R). Black iron-stained shale.

$$
\begin{array}{ll}
\text { Age: } & \text { Indeterminate } \\
\text { Environment: Indeterminate }
\end{array}
$$


Table 5. (cont.)

Kuskokwim Group (cont.)

16-JM-78: Barren. Dark-gray sandy shale.

Age: Indeterminate

Environment: Indeterminate

26-JM-78: Barren. Blact shate.

Age: Indeterminate

Environment: Indeterminate

36-JM-78: Cenosphuera sp. (R). Dark-brown muddy, fine-grained sandstone.

$\begin{array}{ll}\text { Age: } & \text { Indeterminate } \\ \text { Environment: } & \text { Possible maxine }\end{array}$

46-JM-78: Barren, Megaspores? (F), fecal pellets (F), Dark-brown to black sandy shale.
Age:
Indeterminate
Environment: Indeterminate

9-TF-78: Barren. Black silty mudstone.
Age:
Indeterminate
Environment: Indeterminate

13-TF-78: Arenaceous sp.? (R), Black siltstone.
Age:
Indeterminate
Environment: Possible marine

18-TF-78: Barren. Black silty shale.
Age:
Indeterminate
Environment: Indeterminate

39-WL-78: Barren, Black silıy shale.
Age:
Indeterminate
Environment: Indeterminate

43-WL-78: Barren. Fecal pellets (R). Dark-brown sandy shale.
Age:
Indeterminate
Environment: Indeterminale

47-WL-78: Barren. Black silty shale.
Age:
Indeterminate
Environment: Indeterminate

53-WL-78: Barren. Dark-brownish-gray to black muddy, very fine grained sandstone.
Age:
Indeterminate
Envixomment: Indeterminate

56-WL-78: Barren. Black shale,

$$
\begin{array}{ll}
\text { Age: } & \text { Indeterminate } \\
\text { Environment: Indeterminale }
\end{array}
$$


Table 5. (cont.)

Kuskokwim Group (cont.)

61-WL-78: Barren, Dark-brown iron-stained silty shale.

$$
\begin{array}{ll}
\text { Age: } & \text { Indeterminate } \\
\text { Environment: Indeterminate }
\end{array}
$$

65-WL-78: Barren. Black siltstone or very fine grained sandstone.

$$
\begin{array}{ll}
\text { Age: } & \text { Indeterminate } \\
\text { Environment: Indeterminate }
\end{array}
$$

\section{Locality 26}

21-TF-78: Barren. Black fine-grained metasandstone.

$$
\begin{aligned}
& \text { Age: Indeterminate } \\
& \text { Environment: Indeterminate }
\end{aligned}
$$

23-TF-78: Barren. Black shale.

$$
\begin{array}{ll}
\text { Age: } & \text { Indeterminate } \\
\text { Environment: Indeterminate }
\end{array}
$$

25-TF-78: Barren, Black iron-stained shale.

$$
\begin{array}{ll}
\text { Age: } & \text { Indeterminate } \\
\text { Environment: Indeterminate }
\end{array}
$$

$$
\text { Undifferentiated Cretaceous }
$$

Locality 20

4-WL-78: Barren. Dark-gray mudstone.

$$
\begin{array}{ll}
\text { Age: } & \text { Indelerminate } \\
\text { Ervironment: Indeterminate }
\end{array}
$$

8.WL-78: Barren. Yellow-orange phosphatic(?) shale.

$$
\begin{array}{ll}
\text { Age: } & \text { Indeterminate } \\
\text { Environment: Indeterminale }
\end{array}
$$

10-WL-78: Barren. Dark-brown silty mudstone.

$$
\begin{array}{ll}
\text { Age: } & \text { Indeterminate } \\
\text { Environment: Indeterminate }
\end{array}
$$

12-WL-78: Barren. Fecal pellets (A). Buff-tan mudstone.

$$
\begin{array}{ll}
\text { Age: } & \text { Indeterminate } \\
\text { Environment: Indeterminate }
\end{array}
$$

15-WL-78: Barren. Fecal pellets (F). Dark-greenish-gray shale.

$$
\begin{array}{ll}
\text { Age: } & \text { Indeterminate } \\
\text { Environmenl: Indeterminate }
\end{array}
$$

18-WL-78; Barren. Brownish-gray mudstone.

$$
\begin{array}{ll}
\text { Age: } & \text { Indeterminate } \\
\text { Environment: Indeterminate }
\end{array}
$$


Table 5. (cont.)

Undifferentiated Cretaceous (cont.)

22-WL-78: Barren. Dark-brownísh-gray metasiltstone.
Age:
Indeterminate
Environment: Indeterminate

Locality 21

25-WL-78: 8arren. Fecal pellets (F). Dark gray shale.

Age: Indeterminate

Environment: Indeterminate

28-WL-78: Barren. Dark-gray mudstone.

Age: Indeterminate

Environment: Indeterminate

32-WL-78: Barren. Dark-gray mudstone.

Age: Indeterminate

Environment: Indeterminate

Locality 22

34-IP-78: Valuulineria? sp. (R.), fecal pellets (F). Dark-gray iron-stained mudstone.
Age:
Indeterminate
Environment: Possible marine

37-IP-78: Barren. Fecal pellets (F). Dark-gray silty shale.
Age:
Indeterminate
Environment Indeterminate

40-1P-78: Barren. Fecal pellets (C). Dark-gray sandy shale.
Áge:
Indeterminate
Environment: Indeterminate

45-IP-78: Barren. Fecal pellets ( $R$ ). Dark-gray muddy siltstone.
Age:
Indelerminate
Environment: Indelerminate

50-1P-78: Barren. Dark-gray silty shale.
Age:
Indeterminate
Environment: Indeterminate

54-IP-78: Barren. Fecal pellets (F). Black shale.
Age:
Indeterminate
Environment: Indeterminate

57-IP-78: Barren. Fecal pellets (C). Dark-gray silty shale.
Age:
Indeterminate
Environment: Indeterminate 
Table 5. (cont.)

Undifferentiated Cretaceous (cont.)

60-1P-78: Barren. Dark-gray sandy shale,
Age:
Indeterminate
Environment: Indelerminate

Locality 23

67.IP-78: Barren, Black shale.

Age: Indeterminate
Environment: Indeterminate

Locality 24

64-1P-78: Barren. Fecal pellets ( $R$ ). Black shale.
Age:
Indeterminate
Environment: Indeterminate

Undifferentiated Tertiaxy

Locality $\underline{9}$

33-GB-78. Barren. Brown, slightly calcareous mudstone.

Age: Indeterminate

Environment: Indeterminate 
Table 6. Summary of palynological age and environment data.

[ Determinations by Anderson, Warren \& Associates, Inc., San Diego, Caljfornia. Frequency symbols used: $R$, rare; $F$, frequent; $C$, common; $A$, abundant. I

\section{Gemuk Group}

\section{Locality 19}

73-WL-78: Essentially barren of palynomorphs.

$$
\text { Age: Indeterminate }
$$

Environment: Indeterminate

78-WL-78: Undifrerentiated bisaccates (R), Juglans sp. (single), tricolpate grain (single), Micrhystridium sp. (single).
Age:
Probable Tertiary
Environment: Marginal marine(?)

\section{Locality 28}

24-IP-78: Probable surface contaminants: Alnus sp. $(R)$, Pinaceae ( $R$ ), Lycopodiumsporiles sp. (R). Mainly black fusinitic material.
Age:
Indeterminate
Environment: Indeterminate

27-IP-78; Probable surface contaminanls: Alnus sp. ( $R$ ), Pinaceae (R), unidentified tricolpate (single).
Age:
Indeterminate

Environment: Indeterminate

\section{Shaktolik Group}

Locality 2

43.GQ-78: Undifferentiated bisaccates (A), Tsuga sp. (F), Lycopodiumsporites sp. (R), Ainus sp. (R).

$$
\begin{array}{ll}
\text { Age: } & \text { Probable Neogene } \\
\text { Environment: Nonmarine }
\end{array}
$$

Locality 3

57-G8-78: Barren of palynomorphs. Woody and fusinitic material only.
Age:
Indeterminate
Environment: Probable nonmarine

Locality 11

28-GB-78: Pinaceae (single, probable surface contaminant). Mainly woody and fusinitic material.
Age:
Indeterminate
Environment: Probable nonmarine

\section{$\underline{\text { Locality } 15}$}

50-GB-78: Barren of palynomorphs. Smalf recovery of fusinitic and woody material.
Age:
Indeterminale
Environment: Probable nonmarine 
Table 6. (cont.)

Shaktolik Group (cont.)

\section{Locality 17}

48-GB-78: Probable surface contaminants: Laevigalosporiles sp. (R), Belula sp. (R). Mainly woody and fusinitic material.

$$
\begin{array}{ll}
\text { Age: } & \text { Indeterminate } \\
\text { Environment: Probable nonmarine }
\end{array}
$$

\section{Kuskokwim Group}

\section{Localily 25}

2-JM-78: Probable surface conlaminants: Pinaceae (R), Alnus sp. (R), Belula sp. (R). Mainly woody and fusinitic material.
Age:
Indeterminate
Environment: Probable nonmarine

8-JM-78: Probable surlace contaminants: Ainus sp. (R), Belula sp. (R), Sphagnum sp. (R). Mainly woody and fusinitic material.
Age:
Indeterminate
Environment: Probable nonmarine

12-JM-78: Poorly preserved indeterminate spores (R). Mainly woody and fusinitic material.
Age:
Indeterminate
Environment: Probable nonmarine

17.JM-78: Probable surface contaminants: Lycopodium sp. (R), Laevigalosporites sp. (R), Sphagnum sp. (R). Mainly woody and fusinitic material.

Age: Indeterminate

Environment: Probable nonmarine

37-JM-78: Probable surface contaminants: Lycopodium sp. (R), Laevigatosporiles sp. (R), Sphagnum sp. (R). Mainly woody and fusinitic material.

Age: Indeterminate

Environment: Probable nonmarine

10-TF-78: Barren of palynomorphs. Only woody and fusinitic material.
Age:
Indeterminate
Environment: Probable nonmarine

14-TF-78: Organic recoveries similar to above with probable surface contaminants: Alnus sp. (F), Laevigalosporiles sp. (R), Sphagnum sp. (R).
Age:
Indeterminate
Environment: Probable nonmarine

19-TF-78: Organic recoveries similar to above with probable surface contaminants: Alnus sp. (F), Laevigalosporiles sp. (R), Sphagnum sp. (R).

40.WL-78: Essentially barren of palynomorphs. Woody and fusinitic material only.

$$
\begin{array}{ll}
\text { Age: } & \text { Indeterminate } \\
\text { Environment: Prabable nonmorine }
\end{array}
$$


Table 6. (cont.)

Kuskokwim Group (cont.)

44-WL-78: Poorly preserved, indeterminate spores and spore fragments ( $R$ ).
Age:
Indeterminate
Environment: Probable nonmarine

48-WL-78: Probable surface contaminants: Sphagnum sp. (R), Laevigalosporties sp. (R). Pcorly preserved, indeterminate spores $(R)$.
Age:
Indeterminate
Enviromment: Probable nonmarine

54-WL-78: Prabable surface contaminant: Pinaceae (R). Mainly woody and fusinitic material.
Age:
Indeterminate
Environment: Probable nonmarine

62-WL-78: Probable surface contaminant: Lycopodiumsporiles sp. ( $R$ ). Mainly woody and fusinitic material.
Age:
Indeterminate
Environment: Probable nonmarine

66-WL-78: Probable surface contaminant: Lycopodiumsporites sp. (R). Mainly woody and fusinitic material.
Age:
Indeterminate
Environment: Probable nonmarine

$\underline{\text { Locality } 26}$

26-TF-78: Barren of palynomorphs. Mainly fusinitic and woody material.
Age:
Indeterminate
Envixomment: Probable nonmarine

\section{Undifferentiated Cretaceous}

Locality 20

2.WL-78: Poorly preserved indeterminate spores? ( $R$ ).
Age:
Indeterminate
Environment: Probable nonmarine

11-WL-78: Spinidinium vestilum sp. (F).
Age:
Early Cretaceous (Albian)
Environment: Marginal marine

14-WL-78: Undifferentiated bisaccates (F), Tsuga sp. (R), Ornamenlifera echinala (single).
Age:
Cretaceous (probable Albian)
Enviranment: Probable nonmarine

20-WL-78: Undifferentiated bisaccate (R), probable surface contaminant: Alnus sp. (R).

$$
\begin{array}{ll}
\text { Age: } & \text { Indeterminate } \\
\text { Environment: Probable nonmarine }
\end{array}
$$


Table 6. (cont.)

Undifferentiated Cretaceous (cont.)

22-WL.78: Probable surface contaminants: Sphagnum sp. (R), Laevigalosporiles sp. (R).
Age
Indeterminate
Environment: Probable nonmarine

23-WL-78: Spinidinium vestitum sp. (R).
Age:
Early Cretaceous (Albian)
Environment: Marginal marine

Locality 21

26-WL-78: Undifferentialed bisaccates (C), Delloidospon sp. (R), Appendicisporites sp. (single). Spinidinium vestitum sp. (R), Deflandrea? sp. (R).

$$
\text { Age: } \quad \text { Early Cretaceous (Albian) }
$$

Environment: Marginal marine

29-WL-78: Acquitriradiles spinulosus sp. (single), Appendicisporiles sp. (single), Cicalricosisporiles sp. (single). Spinidinium vestitum sp. (R).
Age:
Early Cretaceous (Albien)
Environment: Marginal marine

33-WL-78: Undifrerentiated bisaccates (C), Cicatricosisporites sp. (single). Spinidinium vestilum sp. (R), Deflandrea? sp. (R), Cribroperidinium edwardsi (single).
Age:
Early Cretaceous (Albian)
Environment: Marginal marine

Locality 22

35-IP-78: Undifferentiated bisaccates (R), Osmundacidites sp. $(R)$, poorly preserved indeterminate spores (F).
Age:
Indeterminate
Environment: Probable nonmarine

38-1P-78: Poorly preserved indeterminate spores ( $R$ ).
Age:
Indeterminate
Environment: Probable nonmarine

41-IP-78: Undifferentiated bisaccates (R), Lycopodiumsporites (R), poorly preserved indeterminate spores $(\mathrm{F})$.
Age:
Indeterminate
Environment: Probable nonmarine

46-IP-78: Undifferentiated bisaccates (R).
Age:
Indeterminate
Environment: Probable nonmarine

51-[P-78: Undifferentiated bisaccates (R).
Age:
Indeterminate
Environment: Probable nonmarine 
Table 6. (cont.)

\section{Undifferentiated Cretaceous (cont.)}

55-IP-78: Undifferentiated bisaccates (R), poorly preserved indelerminate spores $\{F\}$

Age: Indeterminate

Environment: Probable nonmarine

61-IP-78: Deltoidospora sp. (R).

Age: Indeterminale

Environment: Probable nonmarine

Locality 23

68.IP-78: Undifferentiated bisaccates $(R)$, poorly preserved indeterminate spores $(R)$.

Age: Indeterminate

Environment: Probable nonmarine

Locality 24

65.IP-78: Undifferentiated bisaccates (C), Osmundacidites? so. (R), Delloidospora? sp. (R). Odontochitina operculata? sp. ( $R$ ), poorly preserved.

Age: Possibly Cretaceous

Environment: Possible marine

\section{Undifferentiated Tertiary}

Locality 1

39-GB-78: Probable surface conlaminant: Laevigotosporites sp. (R).

Age: Indeterminate

Environment: Indeterminate

Locality 9

33-GB-78: Undifferentiated bisaccates (A), Tsuga sp. (A), Lycopodiumsporites sp. (R), Laevigatosporites sp. (R), Alnus sp. (A), Belulaceae sp. (F), Boisduvalia sp. (single).

$\begin{array}{ll}\text { Age: } & \text { Neogene } \\ \text { Environment: Nonmarine }\end{array}$ 
Table 7. Petrographic doto

Locality Sample Rock type

18 13-Rp.78 Fine to med lum sandstoue B5-WL-78 Medium to coarse sandston 1-T-78 Fine sandstone

11.GB $7 \mathrm{~B}$ Medium sandestone

11 27-GB-78 Nedium sindstone

$\begin{array}{lll}12 & 22-G B-78 & \text { Very fine to fine sandy limestone } \\ 15 & 52-G B-78 & \text { Fine to coarse sandstone }\end{array}$

\section{Average}

25 24-7M-78 Calcareons medium to corrse and 28-Mis-78 Medium to coarse andstonte 5-TF-78

49.WL78 Calcarcous mediun to coarse sandetone

$$
\text { Average }
$$

14 16. P.7B Fine to coarse candstone

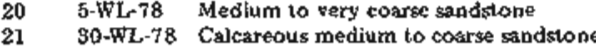

22 42-1P-78 Fine sandy limestone

Coloreous verp line to medium sandstone Average

9. 3A-GB-78 Sily to medium sandy limestone 85.GB.78 Fine sadstione

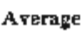

Quartzand

chert (\%) Feldspar (\%) pgetudomatrix (\%) material (\%) authigenic phases Gemuk Group

\begin{tabular}{|c|c|c|}
\hline & 24 & 76 \\
\hline 2 & 13 & 85 \\
\hline & $3 I$ & 73 \\
\hline 3 & 33 & 63 \\
\hline
\end{tabular}

$$
\text { Shintrotik Gronsp }
$$

25
58
6

87

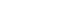$$
25
$$$$
\text { Kuskakwim Group }
$$

$\begin{array}{cl}24 & \text { lron oxide, laumontite } \\ -. & \cdots \\ 17 & \text { Clay, zeolite } \\ 2 & \text { Clag } \\ 20.75 & \end{array}$

Pseudomatrix; laumont ite is replacement. Pseudomatrix; weakly foliated. Psandix.

$\begin{array}{rr}29 & 11 \\ 20 & 15 \\ 24 & 8 \\ 31 & 7 \\ 9 & 23\end{array}$

$\pm 2,8$

43
15
23
63
11 Carbonate, clay, quartz
$2 \quad$ Carbongte
56 Carbonace
Carbonate
Iron oxide, clay
laumontile

21.5

KLakaksin Grou

74

$\begin{array}{rrr}3 & 16 & 81 \\ 17 & 26 & 58\end{array}$

$\begin{array}{rr}37 & 7 \\ 7 & 18\end{array}$

$14 \quad 17.2$$$
68.8
$$

71.5

9

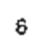

24

22.5

81
56
66
75

Carborate

Cliny, quartz

Clay, quartz

Carbonate, cla

7

Carbanate, clay, quartz

Clay

Clay'

Carbonate

Clay, carbonat

28.6

66 Carbonate
16 Carbonate, chlorite,
quartz
Ductile grain deformation; gerbonate is reDuctile prain deformation; carbonate is replacomtint

Carbonate is largely replacement, Ductìe grain deiormation; weaklyy follated;
clay and lasmonlite are replacements and cy and

Ducille gra in deformation; carbonate is sparry

Duelile grain deformation.

Ductie grain deformation; wreakly foliated. Euctile grain deformation; carbonate is re plstement and gpary coment.

Dyetile grain deformation; carbonate and elay are replacements.

Duelile grat in deformation; carbonale is sparry cement and replacemen. cement and reolucenon; carbonate is sparry

Cprbonate is sparry cement.

Duetile grain deformation except in carbonalecernented areas; carbonate cement is tarys.

and replacement. 
STAFF

Ross G. Schaff, State Geologist

W.W. Barnwell and W.G. Gilbert, Deputy State Geologists

D.D. Adams, Geological assistant

M.D. Albanese, Geological assistant

R.D. Allely, Geological assistant

M.A. Armstrong, Publications specialist

M.R. Ashwell, Minerals laboratory technician

B.G. Baldwin, Clerk typist

E.E. Becia, PIanner

T.A. Benjamin, Chemist

D.L. Bertossa, Geological assistant

J.M. Bird, Clerk-ty pist

M.E. Brown, Land management olficer

T.K. Bundtzen, Geologist

C.D. Burgess, Clerk-ty pist

L.E. Burns, Geological assistant

S.J. Carrick, Hydrologist

S. L. Chambers, Clerk-typist

M.S. Christy, Geologist

R.A. Clay, Hydrologist

d.G. Clough, Geological assistant

E.J. Collazzi, Geological assistant

R.A. Combellick, Geologist

P.L. Coonrod, Secretary

N.W. Crosby, Operation's research analyst

C.L. Daniels, Publications specialist

N.L. Dann, Clerk-typist

J.N. Davies, Geologisl

L.L. Dearborn, Hydrologist

J.E. Decker, Geologist

J.T. Dillon, Geologist

R.G. Dixon, Archaeologist

G.R. Eakins, Geologist

S.V. Garbowski, Geologic in formalion technician

D.E. Gibson, Archaeologią

J.J. Hansen, Geophysicist

S. B. Hardy, Geological assistant

M.W. Benning, Geologist

B.S. Hurtig, Systems analyst

C.E. Holmes, Archaeologist

M.G. Inghram, Hyodrologist

R.W. [reland, Geologist

S.A. Jacques, Cartographer

J.T. Kline, Geologist

S.L. Klingler, Archaeologist

R.W. Kornbrath, Geologist

K.J. Krause, Geologist

D.L. Krouskop, Geophysicist

G.M, Laird, Cartoprapher

E.M. Lamey, Administralive assistant

G.E. LaRoche, Geological assistant

F.L. Larson, Publications specialist

T.A. Little, Geologist

W.E. Long, Hydrologist
W.M. Lyle, Geologist

C.L. Mahan, Accounting technician

R.A. Mann, Clerk

G.D. March, Geologist

M.A. Maurer, Hydrologist

G.A. McCoy, Hydrologist

D.L. McGee, Geologisi

R.D. Merrith, Geologist

J.F. Meyer, Geophysicist

G.W. Mishler, Archaeologist

W.H. Mitchell, Jr., Geological assistant

M.A. Moorman, Geologist

R.J. Motyka, Geologist

C.G. Mull. Geologist

J.A. Munter, Hydrologist

D.J. Mursch, Clerk-typisi

J.N. Newgaard, Accounting Lechnician

C.R. Nichols, Geologist

K.S. Pearson, Cartographer

G.H. Pessel, Geologist

F.H. Pitts, Administrative of ficer

M.K. Polly, Mineral laboratory technician

M.F. Pritchard, Cartographer

S.E. Rawlinson, Geologist

J.W. Reeder, Geologist

D.R. Reger, Archaeologist

R.D. Reger, Geologisi

V.L. Reger, Clerk-typist

M.S. Robinson, Geologist

L.C. Schell, Carlographer

R.D. Slaw, Archaeologist

J.A. Sigler, Clerk

T.E. Smith, Geologist

T.N. Smith, Geologist

D.J. Solie, Geologist

D.R. Stein, Chemist

R.O. Stern, Archaeologist

C.H. Stevenson, Geologic information technician

M.J. Stroebele, Clerk-typist

A.G. Sturmann, Drafting technician

R.W. Stuvek, Land management technician

B.A. Syvertson, Clerk-typist

C.A. Ulery, Geological assistant

R.G. Updike, Geologist

N.C. Veach, Chemist

R.D. Wallace, Operations research analyst

J.L. Weir, Clerk-typist

S.M. Weum, Geophysicist

D.M. Wietchy, Land management officer

B.K. Wilson, Geological assistant

M.A. Wiltse, Chemist

G.M. Zartman, Clerk 